\title{
Polymerization of deoxygenated sickle hemoglobin in the presence of fractionated leaf extracts of Anacardium occidentale, Psidium guajava, and Terminalia catappa
}

\author{
Paul C. Chikezie ${ }^{*} \mathbb{D}$, Raphael C. Ekeanyanwu and Adaeze B. Chile-Agada
}

\begin{abstract}
Background: The present study evaluated levels of polymerization of deoxygenated sickle hemoglobin molecules (poly-dHbS-M) in the presence of fractionated leaf extracts of Anacardium occidentale Linn., Psidium guajava Linn., and Terminalia catappa Linn in vitro as well as identified, quantified, and characterized the phytocomponents from fractionated leaf extracts that exhibited comparatively high potency to impede poly-dHbS-M. Non-hemolyzed sickle erythrocytes were premixed with 40,60 , and $80 \mathrm{mg} / 100 \mathrm{~mL}$ of each of the separate fractionated leaf extracts of $A$. occidentale, P. guajava, and T. catappa in phosphate-buffered saline (PBS; pH = 7.4), osmotically equivalent to $9.0 \mathrm{~g} /$ $\mathrm{L} \mathrm{NaCl}$. Poly-dHbS-M was induced by adding $2.0 \mathrm{~g} / 100 \mathrm{~mL} \mathrm{Na} 2 \mathrm{~S}_{2} \mathrm{O}_{5}$ to the erythrocyte suspension. The absorbance of the erythrocyte suspension was measured at regular intervals of $30 \mathrm{~s}$ for $180 \mathrm{~s}$. Identification, quantification, and characterization of phytocomponents from fractionated leaf extracts were carried out using GC-MS, FT-IR, and UVvisible systems protocols.

Results: The level of poly-dHbS-M of the control sample was significantly higher $(p<0.05)$ than those of the samples containing 40,60, and $80 \mathrm{mg} / 100 \mathrm{~mL}$ ethylacetate extracts of A. occidentale at $t<60 \mathrm{~s}$. The relative cumulative polymerization index (RCPI\%) of dHbS-M in the presence of fractionated leaf extract of $A$. occidentale varied within a wide range of 3.8-59.4\%. A. occidentale (petroleum ether and ethylacetate extracts), P. guajava ( $n$ hexane, chloroform, and ethylacetate extracts), and T. catappa (ethylacetate extract) exhibited comparatively high potency to inhibit poly-dHbS-M.
\end{abstract}

Conclusion: The fractionated leaf extracts of A. occidentale, P. guajava, and T. catappa exhibited differential capacities to impede poly-dHbS-M. The combinations of aliphatic hydrocarbons, methylated esters, methylated fatty acids, aliphatic alcohols, D-erythro-sphinganine, aromatic derivatives, cycloalkanes, phthalates, isothiocyanates, aminated sugars, cyclo-alcohols, and nitro-compounds impeded poly-dHbS-M.

Keywords: Sickle hemoglobin, Anacardium occidentale, Psidium guajava, Terminalia catappa, Polymerization

* Correspondence: p_chikezie@yahoo.com

Department of Biochemistry, Imo State University, Owerri, Nigeria

Springer Open

(c) The Author(s). 2020 Open Access This article is licensed under a Creative Commons Attribution 4.0 International License, which permits use, sharing, adaptation, distribution and reproduction in any medium or format, as long as you give appropriate credit to the original author(s) and the source, provide a link to the Creative Commons licence, and indicate if changes were made. The images or other third party material in this article are included in the article's Creative Commons licence, unless indicated otherwise in a credit line to the material. If material is not included in the article's Creative Commons licence and your intended use is not permitted by statutory regulation or exceeds the permitted use, you will need to obtain permission directly from the copyright holder. To view a copy of this licence, visit http://creativecommons.org/licenses/by/4.0/. 


\section{Background}

Hemoglobin, a tetrameric conjugate protein molecule, is an attractive model for the study of the structure/function relationship of macromolecules. The sickle hemoglobin ( $\mathrm{HbS})$ variant or sickle erythrocyte hemoglobinopathy $\left(\alpha_{2} \beta_{2}{ }^{s}\right)$ is caused by a point mutation affecting the coding sequence of $\beta$-globin gene, whereby thymine is replaced by adenine with the concomitant replacement of adenine by uracil in the triplet code (GAA or GAG codon $\rightarrow$ GUA or GUG codon) - a partially acceptable missense mutation. The mutant gene elicits the substitution of hydrophilic glutamic acid at the $\beta^{6}$ globin position for hydrophobic valine; $\beta^{6 \mathrm{Glu} \rightarrow \mathrm{Val}}$ (Rotter et al. 2005; Bianchi et al. 2009). Hydrophobic $\beta^{6}$ valine (Valbeta6) generates a 'sticky patch' on the $\beta$-globin chains of deoxygenated sickle hemoglobin molecules (dHbS-M) (Martins 1983; Rotter et al. 2005). The contact position on $\mathrm{dHbS}-\mathrm{M}$ is such that the hydrophobic R-group of Val-beta6 appears to fit into a hydrophobic pocket constituted by $\beta^{88}$ leucine (Leu-beta88), $\beta^{85}$ phenylalanine (Phe-beta85), and $\beta^{73}$ aspartic acid (Asp-beta73) residues on adjacent dHbS-M (Adachi et al. 1994; Ferrone et al. 2002; Dash et al. 2013). The hydrophobic interaction is stereospecific of Leu-beta88 side chain in the acceptor pocket regions on adjacent $\mathrm{dHbS}-\mathrm{M}$ (Adachi et al. 1994). The hydrophilic R-group of $\beta^{6}$ glutamic acid (Glubeta6) would not easily fit into the hydrophobic pocket explaining at least part of the reasons deoxyHbA does not polymerize (Martins 1983). The inter-hydrophobic interactions promote nucleation of $\mathrm{dHbS}-\mathrm{M}$ followed by their alignment into microfibrils aggregations of low intracellular solubility, which exert pressure on the interior side of erythrocyte membrane causing mechanical distortion of the erythrocytes (sickle shape) (Rotter et al. 2005). Sodium metabisulfite $\left(\mathrm{Na}_{2} \mathrm{~S}_{2} \mathrm{O}_{5}\right)$ is often used to induce poly-dHbS-M in vitro, which by virtue of its reducing property triggers low oxygen tension required for aggregation of $\mathrm{dHbS}-\mathrm{M}$, engendering morphologically distorted erythrocytes (Oyewole et al. 2008; Uwakwe and Nwaoguikpe, 2008; Nurain et al. 2017).

Epidemiological surveys showed that sickle cell disease (SCD) exerts an enormous burden on public health care system (Stallworth et al. 2010; Adewoyin et al. 2015). Estimates show that SCD affects 20-25 million people globally (Mulumba and Wilson, 2015) and approximately 300,000 children with SCD are born every year in the world, of which $75 \%$ of these births are in Sub-Saharan Africa (Diallo and Tchernia 2002; Weatherall et al. 2006; World Health Organization Regional Office for Africa, 2010; Makani et al. 2013). The dilapidating health challenges and disability-adjusted lifestyle of SCD sufferers are mostly impacted in developing countries (Weatherall et al. 2006). In Africa, SCD accounts for 50-90\% rate of childhood mortality (Grosse et al. 2011). Global epidemiological surveys and the prevalence of SCD is exhaustively reported elsewhere (Mulumba and Wilson 2015). The pathophysiology of SCD is such that management of the disease is often restricted to the use of prophylaxis in concert with drugs that ameliorate the disease symptoms, which offer no therapeutic benefits in form of radical cure.

Presently, hydroxyurea and 2-imidazolines are notable few clinical useful anti-sickling agents that reduce the frequency and severity of sickle cell crises (Chang et al. 1983; Charache et al. 1995; Stallworth et al. 2010; Makani et al. 2013). Hydroxyurea and 5-azacytidine induce the expression of fetal hemoglobin $(\mathrm{HbF})$ via epigenetic regulation of globin gene expression in adult life (Frenette and Atweh 2007). HbF interferes and disrupts aggregation of $\mathrm{dHbS}-\mathrm{M}$ in sickle cell anemia patients by virtue of its $\gamma^{87}$ glutamine (Gln-gamma87) that impedes critical lateral contact regions on the double strand of HbS polymer (Charache et al. 1995; Setty et al. 2000; Cokic et al. 2003; Frenette and Atweh 2007; Eaton and Bunn 2017; Kassa et al. 2019). Toxicity associated with the use of hydroxyurea and 5-azacytidine has previously been reported (Eliot et al. 2006; Frenette and Atweh 2007; Oyewole et al. 2008; Kapoor et al. 2018).

Therapeutic approaches to radical cure of SCD, namely bone marrow transplantation, stem cell transplantation, and gene replacement therapy, in developing countries such as Nigeria and elsewhere, are expensive and remain inaccessible to the vast majority of SCD sufferers (Makani et al. 2013). Where the technology and expertise are available, there are still barriers to the suitability of donors, possibility of immunologic transplant rejection, prognostic uncertainty coupled with endorgan dysfunction, as well as long-term adverse outcomes, which is especially problematic for older patients (Frenette and Atweh 2007; Makani et al. 2013; Kapoor et al. 2018).

The use of prenatal prognostic evaluations, such as amniocentesis, as preventive measures against SCD, is not readily available in Sub-Saharan Africa for the fact the application of this technology is often scarce and expensive where available. Regrettably, clinical counseling to prospective biological parents of SCD sufferers, based on amniocentesis outcome, may advise termination of pregnancy before term, which is often untenable because of negative ethical and cultural considerations.

Chromatographic/spectrometric systems such as gas chromatography-mass spectrometry (GC-MS), Fourier transform-infrared spectrometry (FT-IR), and ultravioletvisible spectroscopy (UV-visible) are used for chemical screening or metabolite profiling of herbal extracts (Sasidharan et al. 2011; Rašković et al. 2015; Chikezie et al. 2015; Ighodaro et al. 2016; Hemavathy et al. 2019). Molecular probe on establishing the structural identities of unknown organic molecules in complex mixtures and the 
vast array of phytochemicals in herbal extracts is achieved by matching the spectra being investigated with reference and standard mass spectra from the library database $\{\mathrm{Na}-$ tional Institute of Standards and Technology (NIST08) library and Wiley7n.l libraries\} (Semwa and Painuli 2019). Furthermore, FT-IR and UV-visible protocols are applied in elucidating structural conformations and molecular nature of functional groups of phytochemicals (Karayil et al. 2014; Rašković et al. 2015; Chikezie et al. 2015).

Previous studies, based on in vitro studies, revealed that the use of vast varieties of crude herbal extracts provides an approach to impede poly-dHbS-M (Oyewole et al. 2008; Chikezie, 2011; Dash et al. 2013; Nurain et al. 2017). Because of physicochemical diversity of vast combinations of phytochemicals from crude herbal extracts, we hypothesize that fractionated leaf extracts of cashew (Anacardium occidentale Linn.), guava (Psidium guajava Linn.), and Indian almond (Terminalia catappa Linn.) will exhibit differential capacities to alter the process leading to the poly- $\mathrm{dHbS}-\mathrm{M}$. The present study evaluated levels of poly- $\mathrm{dHbS}-\mathrm{M}$ in the presence of fractionated leaf extracts of A. occidentale, P. guajava, and T. catappa using in vitro models. Furthermore, the phytocomponents from fractionated leaf extracts of $\mathrm{A}$. occidentale, P. guajava, and T. catappa that exhibited comparatively high potency to impede poly- $\mathrm{dHbS}-\mathrm{M}$, or otherwise, were identified, quantified, and characterized using combined GC-MS, FT-IR and UV-visible systems protocols.

\section{Methods}

\section{Collection and preparation of leaf samples}

Fresh leaves of $A$. occidentale, $P$. guajava, and T. catappa were harvested during the wet season $\left(3^{\text {rd }}-7^{\text {th }}\right.$ April 2019) from private botanical gardens within the environment of Imo State University, Owerri (Latitude $5^{\circ} 30.2237^{\prime} \mathrm{N}$; Longitude $7^{\circ} 2.6277^{\prime} \mathrm{E}$ ), which lies on the rainforest belt of Nigeria. The seeds of the plants were obtained in the wild as non-commercial materials and permissions were not necessary to collect such samples. The collection of plant materials complied with institutional, national, and international guidelines as well as in accordance with local legislation. The harvested leaves of the selected plants used in the present study were identified and authenticated by Professor F.N. Mbagwu of the Department of Plant Science and Biotechnology, Imo State University, Owerri, Nigeria. The voucher numbers were assigned as follows: A. occidentale: IMSUH-009; P. guajava: IMSUH-010; T. catappa: IMSUH-011 and the plant specimens were deposited in the department herbarium.

Thereafter, the leaves were washed and air-dried at ambient laboratory temperature of $25 \pm 5{ }^{\circ} \mathrm{C}$ pending extraction within $24 \mathrm{~h}$ of collection of the leaf samples.
The preparation of the leaves for extraction was according to the methods previously described (Ojiako et al. 2015). Eight hundred grams (800 g) part of the chopped fresh leaves were weighed using a triple beam balance (OHAU 750-50; OHAUS Triple Beam Balance, Model TJ611, Burlington, NC, USA) and dried to constant weight in an oven (WTC BINDER; 7200 Tuttlinge, Germany) at $50{ }^{\circ} \mathrm{C}$ for $10-12 \mathrm{~h}$ as previously described (Ezekwe and Chikezie 2017). Thomas-Willey milling machine (ASTM D-3182; India) was used to grind the dried leaf samples into powder. The powdered leaf samples were sieved on a wire mesh screen $\left(1 \times 1 \mathrm{~mm}^{2}\right)$ to remove relatively large particles. Finally, the fine ground leaf samples were stored at $4{ }^{\circ} \mathrm{C}$ in air-tight screwcapped bottles pending extraction and fractionation.

\section{Extraction and fractionation of leaf extracts}

Extraction of $300 \mathrm{~g}$ of the dried ground samples was carried out in $2000 \mathrm{~mL}$ of ethanol/water mixture; 1:1 v/v using repeated cycles of Soxhlet extraction protocol for $18 \mathrm{~h}$ to obtain a final volume of $500 \mathrm{~mL}$ of each herbal extracts (Ojiako et al. 2015). Preparation of fractionated leaf extracts of $A$. occidentale, P. guajava, and T. catappa was according to the methods previously described by Okoye et al. (2010) but with modifications. Separate volumes of the crude hydro-ethanolic leaf extracts were transferred into corresponding separating funnels. Fractionation of the crude hydro-ethanolic leaf extracts was carried out by successive partitioning using equal volumes of solvents in the order of increasing polarities, namely petroleum ether, $n$-hexane, chloroform, and ethylacetate.

Corresponding fractionated leaf extracts, namely petroleum ether-, $n$-hexane-, chloroform-, ethylacetate-, as well as the residual aqueous extracts, were concentrated under reduced pressure in a rotary evaporator (Büch Rotavapor $\mathrm{R}-200)$ for $12 \mathrm{~h}$ at $50{ }^{\circ} \mathrm{C}$ and the residues dried in a vacuum desiccator. The yield of the fractionated leaf extracts was calculated as ratio of dried weight of the extract to $100 \mathrm{~g}$ of the dried ground leaf sample. Portions of the fractionated leaf extracts were suspended in measured volumes of phosphate-buffered saline (PBS); $\mathrm{pH}=7.4$, osmotically equivalent to $9.0 \mathrm{~g} / \mathrm{L}$ sodium chloride $(\mathrm{NaCl}) \quad\left\{.0 \mathrm{~g} \mathrm{NaCl}, 1.71 \mathrm{~g} \quad \mathrm{Na}_{2} \mathrm{HPO}_{4} \cdot 2 \mathrm{H}_{2} \mathrm{O}\right.$, and $2.43 \mathrm{~g} \mathrm{NaH}_{2} \mathrm{PO}_{4} \cdot 2 \mathrm{H}_{2} \mathrm{O}$ per liter\} to give standard solutions of the extracts used for $\mathrm{HbS}$ polymerization studies.

\section{Exclusion criteria}

The guidelines previously reported (Yamamoto et al. 2014) was used as bases for exclusion criteria for participants. The exclusion criteria include participants who were on routine medications, received blood transfusion and infusion for at least 4 weeks prior to blood sampling. Furthermore, blood samples were thoroughly 
cross-checked for the presence of clot before used for the experiment.

\section{Collection and preparation of blood samples}

Venous blood samples were collected by venipuncture, between 7th of May and 28th of July, 2019, from 108 consenting individuals of homozygous sickle hemoglobin (HbSS) genotype under the auspices of Rehoboth Christian Medical Center, Nwaoruebi and Easter Summit Specialist Clinics and Maternity, Amakohia. The clinics are located in Imo State, Owerri, Nigeria. The blood samples were stored in EDTA anticoagulant tubes. The genotype of the blood samples was further subjected to a confirmatory test using cellulose acetate electrophoretic methods previously described (Bain et al. 2012).

The HbS erythrocytes were washed using centrifugation methods as described (Tsakiris et al. 2005) with modifications according to previous reports (Chikezie, 2011; Chikezie and Uwakwe 2011). Within 2 h of collection of the blood sample, a portion of $4.0 \mathrm{~mL}$ of the sample was introduced into a centrifuge test tube containing $4.0 \mathrm{~mL}$ of $\mathrm{PBS} ; \mathrm{pH}=7.4$. The erythrocytes were separated from plasma by centrifugation at $1200 \times g$ for $10 \mathrm{~min}$. The protocol was repeated three times. The erythrocytes were finally re-suspended in $5.0 \mathrm{~mL}$ of PBS and used for polymerization studies of $\mathrm{dHbS}-\mathrm{M}$.

\section{Sickle hemoglobin polymerization studies}

Polymerization studies of $\mathrm{dHbS}-\mathrm{M}$ were carried out according to the modified methods previously described (Chikezie 2011), whereby non-hemolyzed HbSS erythrocytes were used instead of hemolysate samples. A 0.1 $\mathrm{mL}$ of HbSS erythrocyte suspension (10\% hematocrit) was mixed with $0.5 \mathrm{~mL}$ PBS, followed by the introduction of an additional $1.0 \mathrm{~mL}$ of PBS in a test tube. The mixture was transferred into a cuvette and $3.4 \mathrm{~mL}$ of 2.0 $\mathrm{g} / 100 \mathrm{~mL}$ aqueous solution of $\mathrm{Na}_{2} \mathrm{~S}_{2} \mathrm{O}_{5}$ was added. The absorbance of the assay mixture was measured at a maximum wavelength $(\lambda \max )=700 \mathrm{~nm}$, at regular intervals of $30 \mathrm{~s}$ for $180 \mathrm{~s}$, using a spectrophotometer (Digital Blood Analyzer; SPECTRONIC 20; Labtech, LabX, Bay Street, Midland, ON, Canada) (control assay). The procedure was repeated substituting the $1.0 \mathrm{~mL}$ of PBS with corresponding three increasing concentrations $(40,60$, and $80 \mathrm{mg} / 100 \mathrm{~mL}$ ) of each of the separate fractionated leaf extracts (test assay). Relative poly-dHbS-M (\%) was calculated according to the formula previously described (Chikezie et al. 2010; Chikezie 2011).

$$
\% \mathrm{RP}=\frac{\mathrm{A}_{\mathrm{t} / \mathrm{c}}}{\mathrm{A}_{\mathrm{c} 180^{\mathrm{th}} \mathrm{s}}} \times 100
$$

where:

\%RP: relative poly-dHbS-M (\%)
$A_{t / c}:$ absorbance of test/control sample at a given time (second)

$\mathrm{A}_{\mathrm{c} 180}{ }^{\text {th }} \mathrm{s}$ : absorbance of control sample at the $180^{\text {th }}$ second

\section{Inhibition/activation of poly-dHbS-M}

Arithmetically, the percentage inhibition/activation of poly-dHbS-M by the leaf extracts at a given experimental time interval was obtained thus:

$$
\% \mathrm{I} \backslash \mathrm{A}=\% \mathrm{PC}_{\mathrm{ct}}-\% \mathrm{PT}_{\mathrm{ct}}
$$

where:

$\% \mathrm{IA}$ : percentage inhibition or activation of polydHbS-M

$\% \mathrm{PC}_{\mathrm{ct}}: \% \mathrm{RP}$ of the control sample at a given experimental time interval

$\% \mathrm{PT}_{\mathrm{ct}}: \% \mathrm{RP}$ of the test sample at a given experimental time interval corresponding to that of the control sample

Note: The algebraic sum of percentage activation of poly- $\mathrm{dHbS}-\mathrm{M}$ is negative, whereas percentage inhibition of poly-dHbS-M is positive in the presence of the leaf extract.

\section{Cumulative polymerization index}

The cumulative inhibition/activation of poly-dHbS-M within the experimental time of $180 \mathrm{~s}$ is defined by a measure of the Area under the Curve (AUC) of the plot of \% RP versus time (s).

Using the Simpson's rule, thus:

$$
f\left(x_{1}\right) h_{1}+f\left(x_{2}\right) h_{2}+\ldots .+f\left(x_{n}\right) h_{n}
$$

This is given by:

$$
\begin{aligned}
& \text { AUC (polymerization } \% \text {.second }) \\
& \quad=\frac{t}{2}\left(x_{n}+2 x_{n-1}+2 x_{n-2}+2 x_{n-3}+\ldots x_{n-\infty}\right)
\end{aligned}
$$

where:

$\mathrm{t}$ : time intervals of $30 \mathrm{~s}$

$\mathrm{x}$ : \% RP at corresponding time interval

Thus:

$$
\mathrm{RCPI} \%=\frac{\mathrm{AUC}_{\text {Control }}-\mathrm{AUC}_{\text {Test }}}{\mathrm{AUC}_{\text {Control }}} \times 100
$$

where:

RCPI\%: relative cumulative polymerization index

Note: A positive RCPI\% connotes cumulative inhibition of poly-dHbS-M, whereas negative RCPI\% connotes cumulative activation of poly-dHbS-M by the leaf extract. 


\section{Spectrometry}

The identification, quantification, and characterization of phytocomponents from fractionated leaf extracts of $A$. occidentale, $P$. guajava, and T. catappa were carried out using standard chromatographic/spectrometric protocols, viz. GC-MS systems (Agilent 7890A GC system set up with 5975C VL MSD, Agilent Technologies, Inc., Santa Clara, CA, USA) operated as previously described (Rašković et al. 2015). The MS system was accomplished in electron ionization (EI) mode with selected ion monitoring (SIM). FT-IR and UV-visible instruments (PerkinElmer Spectrophotometer, USA) were performed according to the methods previously described (Ighodaro et al. 2016; Hemavathy et al. 2019).

\section{Statistical analyses}

The data collected were expressed in means $(X) \pm \mathrm{SD}$ and analyzed in one-way ANOVA and least significance difference (LSD). The comparison was made between groups and significance was established by ANOVA at 95\% confidence level. The difference of $p<0.05$ was considered statistically significant.

\section{Results}

\section{Percentage yields of fractionated leaf extracts}

The percentage yields of the fractionated leaf extracts of A. occidentale, P. guajava, and T. catappa are presented in Table 1. The aggregate yields of petroleum ether, $n$ hexane, chloroform, ethylacetate, and residual aqueous fractions of the leaf extracts were A. occidentale (13.017 g per $100 \mathrm{~g}$ dry leaf sample), P. guajava (9.627 g per 100 $\mathrm{g}$ dry leaf sample), and T. catappa (10.060 g per $100 \mathrm{~g}$ dry leaf sample). The residual aqueous fractions of the leaf extracts gave corresponding highest percentage yields (Table 1).

\section{Levels of poly-dHbS-M in the presence of fractionated leaf extracts of $A$. occidentale}

Figure 1a-e showed the levels of poly-dHbS-M of the control sample and in the presence of fractionated leaf extract of $A$. occidentale with the progression of experimental time. The control sample exhibited a comparatively higher level of poly-dHbS-M than those of the samples containing 40,60 , and $80 \mathrm{mg} / 100 \mathrm{~mL}$ petroleum ether extracts of $A$. occidentale within the experimental time range of $0 \mathrm{~s} \leq t \leq 120 \mathrm{~s}$ (Fig. 1a).
Specifically, at $t=30 \mathrm{~s}, 40 \mathrm{mg} / 100 \mathrm{~mL}$ petroleum ether extract of $A$. occidentale caused significantly lower $(p<$ 0.05 ) level of poly-dHbS-M than the control sample as well as the samples containing 60 and $80 \mathrm{mg} / 100 \mathrm{~mL}$ petroleum ether extracts of $A$. occidentale (Fig. 1a). Conversely, at $t=30 \mathrm{~s}$, the levels of poly-dHbS-M of the control sample, as well as the samples containing 60 and $80 \mathrm{mg} / 100 \mathrm{~mL}$ petroleum ether extracts of $A$. occidentale, showed no significant difference $(p>0.05)$.

Figure $1 \mathrm{~b}$ showed the levels of poly-dHbS-M of the control sample and samples containing $n$-hexane extract of A. occidentale. An overview of Fig. 1b showed that the pattern of levels of poly-dHbS-M of the control sample and sample containing $80 \mathrm{mg} / 100 \mathrm{~mL} n$-hexane extract of $A$. occidentale were biphasic. For instance, at $t<60 \mathrm{~s}$, the control sample and sample containing 80 $\mathrm{mg} / 100 \mathrm{~mL} n$-hexane extract of $A$. occidentale exhibited exponential increasing levels of poly-dHbS-M, which was followed by a phase of decreasing levels of poly$\mathrm{dHbS}-\mathrm{M}$. The peak levels of poly-dHbS-M of samples containing 40 and $60 \mathrm{mg} / 100 \mathrm{~mL} n$-hexane extracts of A. occidentale occurred at $t=90 \mathrm{~s}$, which was followed by moderate decreasing levels of poly-dHbS-M as experimental time progressed. The maximum level of poly-dHbS-M of the control sample, at $t=60 \mathrm{~s}$, was significantly higher $(p<0.05)$ than those of samples containing 40,60 , and $80 \mathrm{mg} / 100 \mathrm{~mL} n$-hexane extracts of A. occidentale. Conversely, at $t=180 \mathrm{~s}$, the levels of poly-dHbS-M of the sample containing 40,60 , and 80 $\mathrm{mg} / 100 \mathrm{~mL} n$-hexane extracts of A. occidentale were significantly higher $(p<0.05)$ than that of the control sample.

Figure 1c showed that the pattern of levels of poly$\mathrm{dHbS}-\mathrm{M}$ of the control sample, as well as samples containing 40, 60, and $80 \mathrm{mg} / 100 \mathrm{~mL}$ chloroform extracts of A. occidentale, were biphasic. A peak level of poly$\mathrm{dHbS}-\mathrm{M}$ of the control sample was at $t=90 \mathrm{~s}$, whereas those of the samples containing 60 and $80 \mathrm{mg} / 100 \mathrm{~mL}$ chloroform extracts of $A$. occidentale were at $t=60 \mathrm{~s}$. Figure 1c showed that the level of poly-dHbS-M of the sample containing $40 \mathrm{mg} / 100 \mathrm{~mL}$ chloroform extract of A. occidentale peaked at $t=30 \mathrm{~s}$. An overview of Fig. 1c showed that 40 and $60 \mathrm{mg} / 100 \mathrm{~mL}$ chloroform extracts of $A$. occidentale caused significant higher $(p<0.05)$ levels of poly-dHbS-M compared with that of the control sample. Additionally, within the experimental time

Table 1 Yields of fractionated leaf extracts

\begin{tabular}{|c|c|c|c|c|c|}
\hline \multirow{2}{*}{$\begin{array}{l}\text { Extract } \\
\text { fractions }\end{array}$} & \multicolumn{5}{|c|}{ Yield (g per $100 \mathrm{~g}$ dry leaf sample); w/w ratio } \\
\hline & Petroleum ether & n-hexane & Chloroform & Ethylacetate & Residual aqueous \\
\hline A. occidentale & 2.017 & 0.470 & 0.177 & 0.153 & 10.20 \\
\hline P. guajava & 1.091 & 0.763 & 0.100 & 0.473 & 7.20 \\
\hline T. catappa & 0.340 & 0.630 & 0.013 & 0.077 & 9.00 \\
\hline
\end{tabular}




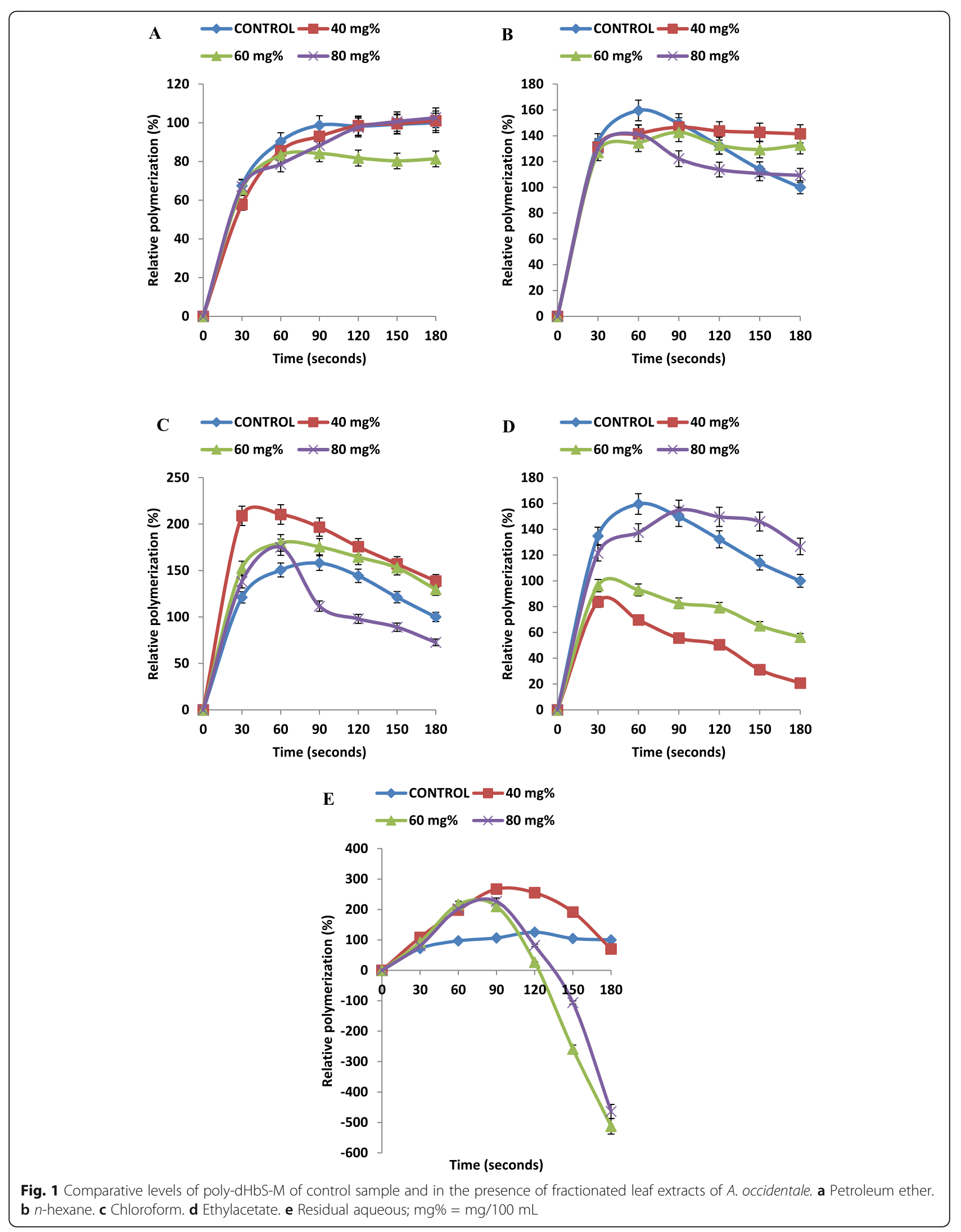


of $t<60 \mathrm{~s}$, the sample containing $80 \mathrm{mg} / 100 \mathrm{~mL}$ chloroform extract exhibited a significant higher $(p<0.05)$ level of poly-dHbS-M. Conversely, at $t>60 \mathrm{~s}, 80 \mathrm{mg} / 100 \mathrm{~mL}$ chloroform extract caused significantly lower $(p<0.05)$ level of poly-dHbS-M compared with the control sample.

Figure 1d showed the biphasic pattern of levels of poly-dHbS-M of the control sample as well as that of the samples containing 40,60, and $80 \mathrm{mg} / 100 \mathrm{~mL}$ ethylacetate extracts of $A$. occidentale, in which the samples exhibited an exponential increase in their levels of poly$\mathrm{dHbS}-\mathrm{M}$ within the experimental time of $t<30 \mathrm{~s}$.

Figure 1d showed that the control sample gave a peak level of poly-dHbS-M at $t=60 \mathrm{~s}$, whereas that of $80 \mathrm{mg} /$ $100 \mathrm{~mL}$ ethylacetate extract of $A$. occidentale peaked at $t=$ $90 \mathrm{~s}$. Additionally, the peak levels of poly-dHbS-M of the samples containing 40 and $60 \mathrm{mg} / 100 \mathrm{~mL}$ ethylacetate extracts of $A$. occidentale occurred at $t=30 \mathrm{~s}$. The level of poly-dHbS-M of the control sample was significantly higher $(p<0.05)$ than those of the samples containing 40 , 60 , and $80 \mathrm{mg} / 100 \mathrm{~mL}$ ethylacetate extracts of $A$. occidentale at $t<60 \mathrm{~s}$ (Fig. 1d). Conversely, at $t>90 \mathrm{~s}$, the sample containing $80 \mathrm{mg} / 100 \mathrm{~mL}$ ethylacetate extract of $A$. occidentale exhibited significantly higher $(p<0.05)$ levels of poly-dHbS-M than the control sample and samples containing 40 and $60 \mathrm{mg} / 100 \mathrm{~mL}$ ethylacetate extracts of $A$. occidentale. The sample containing $40 \mathrm{mg} / 100 \mathrm{~mL}$ ethylacetate extract of $A$. occidentale gave the lowest level of poly-dHbS-M compared with other experimental samples $(p<0.05)$.

Figure 1e showed that the maximum level of poly$\mathrm{dHbS}-\mathrm{M}$ of the control sample was at $t=120 \mathrm{~s}$, whereas those of the sample containing 40, 60, and $80 \mathrm{mg} / 100$ $\mathrm{mL}$ residual aqueous extracts of $A$. occidentale peaked at $t=90 \mathrm{~s}$. Furthermore, the levels of poly-dHbS-M of the sample containing 40,60 , and $80 \mathrm{mg} / 100 \mathrm{~mL}$ residual aqueous extracts of $A$. occidentale were significantly higher $(p<0.05)$ than that of the control sample. However, at $t>120 \mathrm{~s}$, the sample containing 60 and $80 \mathrm{mg} /$ $100 \mathrm{~mL}$ residual aqueous extracts of $A$. occidentale exhibited exponential decreasing levels of poly-dHbS-M, which were significantly lower $(p<0.05)$ than that of the control sample. The levels of poly-dHbS-M of samples containing 60 and $80 \mathrm{mg} / 100 \mathrm{~mL}$ residual aqueous extracts of $A$. occidentale gave negative numerical values at approximately $t>120 \mathrm{~s}$ and $t>135 \mathrm{~s}$ respectively (Fig. $1 \mathrm{e})$. At the end of the experimental time, the levels of poly-dHbS-M of the sample containing 40,60 , and 80 $\mathrm{mg} / 100 \mathrm{~mL}$ residual aqueous extracts of $A$. occidentale were significantly lower $(p<0.05)$ than that of the control sample. Within the experimental time range of $90 \mathrm{~s}$ $\leq t \leq 150 \mathrm{~s}$, the level of poly-dHbS-M of the sample containing $40 \mathrm{mg} / 100 \mathrm{~mL}$ residual aqueous extract of $A$. occidentale was significantly higher $(p<0.05)$ than that of the control sample.

\section{Levels of poly-dHbS-M in the presence of fractionated leaf extracts of $P$. guajava}

The levels of poly-dHbS-M of the control sample and in the presence of fractionated leaf extracts of $P$. guajava with experimental time are presented in Fig. 2a-e. Figure 2a showed that the levels of poly-dHbS-M of the control sample and the samples containing 40, 60, and $80 \mathrm{mg} / 100 \mathrm{~mL}$ petroleum ether extracts of $P$. guajava were biphasic. The first phase showed an exponentially increasing level of poly-dHbS-M of the control sample, which peaked at $t=90 \mathrm{~s}$. The levels of poly-dHbS-M of the test samples peaked at $t=60 \mathrm{~s}$. It is worthwhile to note that the levels of poly-dHbS-M of the samples containing 40, 60, and $80 \mathrm{mg} / 100 \mathrm{~mL}$ petroleum ether extracts of $P$. guajava showed no significant difference $(p>0.05)$ within the experimental time of $t<90 \mathrm{~s}$.

Figure 2a showed that the second phase of poly-dHbS$\mathrm{M}$ of the control sample and the sample containing 40, 60 , and $80 \mathrm{mg} / 100 \mathrm{~mL}$ petroleum ether extracts of $P$. guajava exhibited decreasing levels of poly-dHbS-M as experimental time increased. Additionally, the decreasing levels of poly-dHbS-M of the test samples were depended on the concentrations of the herbal extracts, which were in the order: $80 \mathrm{mg} / 100 \mathrm{~mL}>60 \mathrm{mg} / 100$ $\mathrm{mL}>40 \mathrm{mg} / 100 \mathrm{~mL}$. Overall, the level of poly-dHbS-M of the control sample was significantly lower $(p<0.05)$ than those of the test samples.

Figure2b showed the levels of poly-dHbS-M of the control and test samples. The pattern of level of poly$\mathrm{dHbS}-\mathrm{M}$ of the sample containing $80 \mathrm{mg} / 100 \mathrm{~mL} n$-hexane extract of $P$. guajava was biphasic. The levels of poly-dHbS-M of the samples containing 40,60 , and 80 $\mathrm{mg} / 100 \mathrm{~mL} n$-hexane extracts of $P$. guajava were significantly different $(p<0.05)$ within the experimental time; except at $t=90 \mathrm{~s}$.

Figure 2c showed that, within the experimental time range of $90 \mathrm{~s} \leq t \leq 180 \mathrm{~s}$, the level of poly-dHbS-M of the control sample was significantly higher $(p<0.05)$ than those of the samples containing 40,60 , and $80 \mathrm{mg} /$ $100 \mathrm{~mL}$ chloroform extracts of $P$. guajava. Conversely, the levels of poly-dHbS-M of the control and test samples exhibited no significant difference $(p>0.05)$ within the experimental time of $t<90 \mathrm{~s}$. The pattern of levels of poly-dHbS-M of the test samples was biphasic, which exhibited an exponential increase in the level of poly$\mathrm{dHbS}-\mathrm{M}$ at $t<60 \mathrm{~s} ; p>0.05$.

Figure $2 \mathrm{~d}$ showed that the levels of poly-dHbS-M of the samples containing 40 and $80 \mathrm{mg} / 100 \mathrm{~mL}$ ethylacetate extracts of $P$. guajava were significantly lower $(p<0.05)$ than that of the control sample. Conversely, the level of poly-dHbS-M of the sample containing $60 \mathrm{mg} / 100 \mathrm{~mL}$ ethylacetate extract of $P$. guajava was significantly higher $(p<0.05)$ than that of the control sample. An overview of Fig. $2 \mathrm{~d}$ showed that the pattern of levels of poly-dHbS-M 

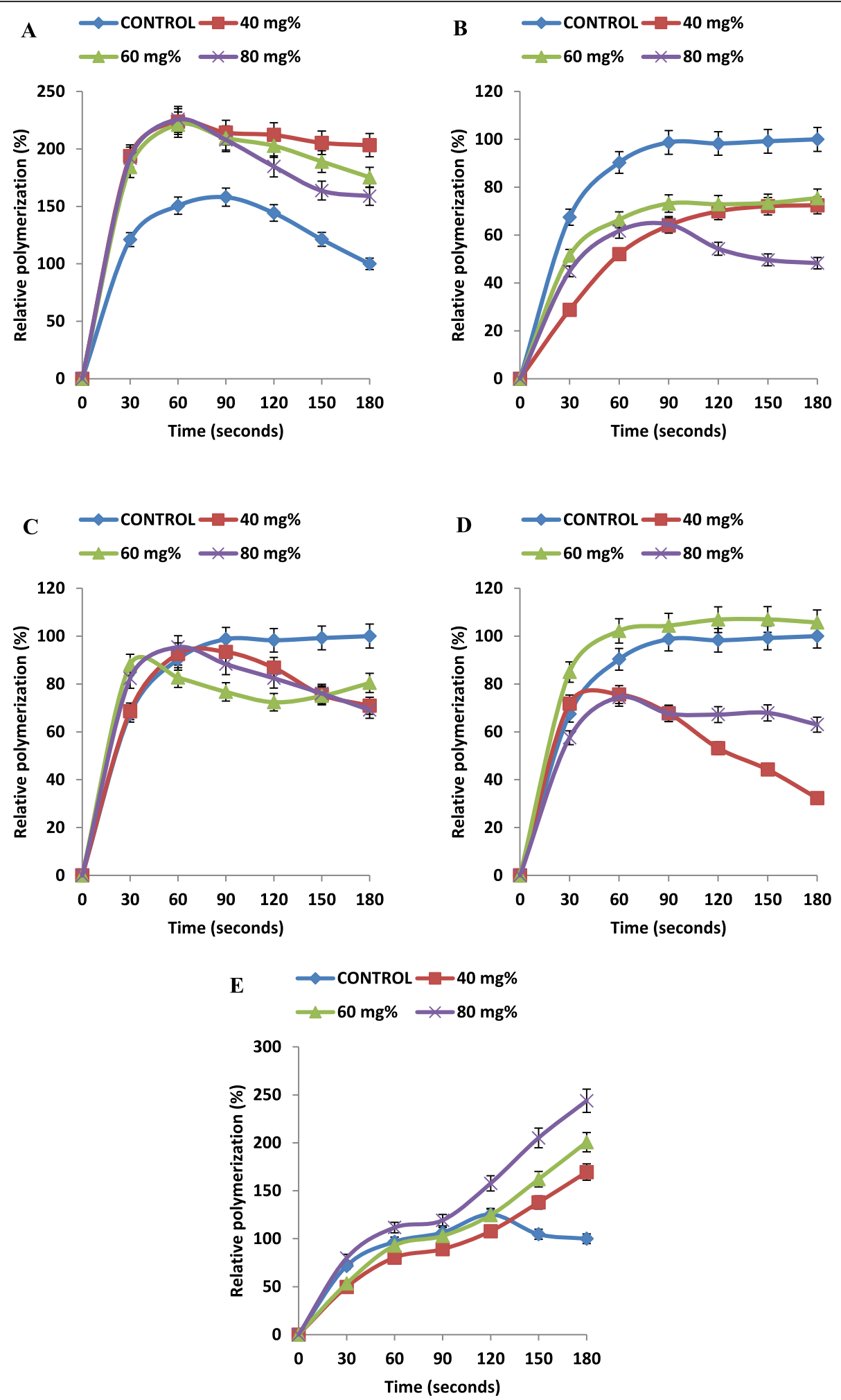

Fig. 2 Comparative levels of poly-dHbS-M of control sample and in the presence of fractionated leaf extracts of $P$. guajava. a Petroleum ether. $\mathbf{b}$ $n$-hexane. c Chloroform. d Ethylacetate. e Residual aqueous; $\mathrm{mg} \%=\mathrm{mg} / 100 \mathrm{~mL}$ 
of 40 and $80 \mathrm{mg} / 100 \mathrm{~mL}$ ethylacetate extracts of $P$. guajava was biphasic. Additionally, the levels of poly-dHbS-M in the presence of 40 and $80 \mathrm{mg} / 100 \mathrm{~mL}$ ethylacetate extracts of $P$. guajava showed no significant difference $(p>0.05)$ within the time range of $60 \mathrm{~s} \leq t \leq$ $90 \mathrm{~s}$, in which the peak value of poly-dHbS-M was at $t=60 \mathrm{~s}$. The levels of poly-dHbS-M of the control sample and the sample containing $40 \mathrm{mg} / 100 \mathrm{~mL}$ ethylacetate extract of $P$. guajava showed no significant difference at $t<30 \mathrm{~s}(p>0.05)$.

Figure $2 \mathrm{e}$ showed that within the experimental time range of $90 \mathrm{~s} \leq t \leq 180 \mathrm{~s}$, the increasing levels of poly$\mathrm{dHbS}-\mathrm{M}$ of the test samples were in a concentrationdependent manner; i.e., $80 \mathrm{mg} / 100 \mathrm{~mL}>60 \mathrm{mg} / 100 \mathrm{~mL}>$ $40 \mathrm{mg} / 100 \mathrm{~mL}$. However, the level of poly-dHbS-M of 40 $\mathrm{mg} / 100 \mathrm{~mL}$ residual aqueous extract of $P$. guajava was significantly lower $(p<0.05)$ than that of the control sample at $t<120 \mathrm{~s}$. Likewise, the level of poly-dHbS-M of the sample containing $60 \mathrm{mg} / 100 \mathrm{~mL}$ of residual aqueous extract was significantly lower $(p<0.05)$ than that of the control sample at $t=30 \mathrm{~s}$, which was contrary within the time range of $60 \mathrm{~s} \leq t \leq 120 \mathrm{~s} ; p>0.05$ (Fig. 2e).

Within the experimental time, the level of poly-dHbS$\mathrm{M}$ of the sample containing $80 \mathrm{mg} / 100 \mathrm{~mL}$ residue aqueous extract of $P$. guajava was significantly higher $(p$ $<0.05)$ than that of the control sample. Furthermore, at $t>120 \mathrm{~s}$, the levels of poly-dHbS-M of the sample containing 40,60 , and $80 \mathrm{mg} / 100 \mathrm{~mL}$ residue aqueous extracts of $P$. guajava were significantly higher $(p<0.05)$ than that of the control sample. The level of poly-dHbS$\mathrm{M}$ of the control sample was biphasic with a peak value at $t=120 \mathrm{~s}$ (Fig. 2e).

\section{Levels of poly-dHbS-M in the presence of fractionated leaf extracts of $T$. catappa}

Figure 3a-e showed the levels of poly-dHbS-M of the control sample and the samples containing 40,60, and $80 \mathrm{mg} /$ $100 \mathrm{~mL}$ of fractionated leaf extracts of T. catappa with experimental time. Figure 3a showed that the pattern of levels of poly-dHbS-M of the test samples was biphasic. The levels of poly-dHbS-M of the samples containing 40, 60, and $80 \mathrm{mg} / 100 \mathrm{~mL}$ petroleum ether extracts peaked at $t=$ $90 \mathrm{~s}, t=90 \mathrm{~s}$, and $t=30 \mathrm{~s}$ respectively. The levels of poly$\mathrm{dHbS}-\mathrm{M}$ of the samples containing 60 and $80 \mathrm{mg} / 100 \mathrm{~mL}$ of petroleum ether extracts were significantly lower $(p<$ 0.05 ) than that of the control sample at $t>150 \mathrm{~s}$, whereas the sample containing $40 \mathrm{mg} / 100 \mathrm{~mL}$ petroleum ether extract showed no significant difference $(p>0.05)$ from that of the control sample at $t=180 \mathrm{~s}$.

Figure $3 \mathrm{~b}$ showed that within the experimental time of $t<90 \mathrm{~s}$, the levels of poly-dHbS-M of the samples containing 40,60 , and $80 \mathrm{mg} / 100 \mathrm{~mL} n$-hexane extracts of $T$. catappa were significantly higher $(p<0.05)$ than the control sample. Conversely, at $t>120 \mathrm{~s}$, the levels of
poly-dHbS-M of the test samples was significantly lower $(p<0.05)$ than that of the control sample.

Within the experimental time of $t<180 \mathrm{~s}$, the level of poly-dHbS-M of the sample containing $80 \mathrm{mg} / 100 \mathrm{~mL}$ chloroform extract of $T$. catappa was significantly lower $(p<0.05)$ than that of the control sample (Fig. 3c). Likewise, the sample containing $60 \mathrm{mg} / 100 \mathrm{~mL}$ chloroform extract of $T$. catappa gave significantly lower $(p<0.05)$ level of poly-dHbS-M within the experimental time range of $60 \mathrm{~s} \leq t \leq 120 \mathrm{~s}$. The levels of poly-dHbS-M of the samples containing 40 and $60 \mathrm{mg} / 100 \mathrm{~mL}$ chloroform extracts of $T$. catappa were significantly higher $(p<0.05)$ than that of the control sample at $t=30 \mathrm{~s}$. Additionally, at $t>150 \mathrm{~s}$, the level poly-dHbS-M of the sample containing $40 \mathrm{mg} /$ $100 \mathrm{~mL}$ chloroform extract was significantly higher $(p<$ $0.05)$ than that of the control sample.

Figure $3 \mathrm{~d}$ showed that within the experimental time, $t>$ $120 \mathrm{~s}$, the level of poly-dHbS-M of the sample containing $40 \mathrm{mg} / 100 \mathrm{~mL}$ ethylacetate extract of T. catappa was significantly higher $(p<0.05)$ than that of the control sample. The levels of poly-dHbS-M of test samples showed no significant difference $(p>0.05)$ from that of the control sample at $t=30 \mathrm{~s}$. Furthermore, at $t=60 \mathrm{~s}$, the level of poly$\mathrm{dHbS}-\mathrm{M}$ in the presence of the sample containing $40 \mathrm{mg} /$ $100 \mathrm{~mL}$ ethylacetate extract of T. catappa was significantly lower $(p<0.05)$ than that of the control sample. Within the experimental time, the levels of poly-dHbS-M of the test samples were significantly different $(p<0.05)$ in a concentration-dependent manner; except between samples containing 40 and $60 \mathrm{mg} / 100 \mathrm{~mL}$ ethylacetate extract of $T$. catappa at $t=60 \mathrm{~s} ; p>0.05$.

Figure 3 showed that within the experimental time, the level of poly-dHbS-M of the sample containing 40 $\mathrm{mg} / 100 \mathrm{~mL}$ residual aqueous extract of $T$. catappa was significantly higher $(p<0.05)$ than those of the control sample as well as the samples containing 60 and $80 \mathrm{mg} /$ $100 \mathrm{~mL}$ residual aqueous extracts of $T$. catappa; except at $t=180 \mathrm{~s} ; p>0.05$.

The level of poly-dHbS-M of the sample containing 60 $\mathrm{mg} / 100 \mathrm{~mL}$ residue aqueous extract of T. catappa was significantly lower $(p<0.05)$ than that of the control sample at $t<120 \mathrm{~s}$. The level of poly-dHbS-M of the sample containing $80 \mathrm{mg} / 100 \mathrm{~mL}$ residual aqueous extract of $T$. catappa was significantly lower $(p<0.05)$ than that of the control sample at $t<120 \mathrm{~s}$; but was not significantly different $(p>0.05)$ from that of the control sample at $t=30$ s. At the end of the experimental time, the level of poly$\mathrm{dHbS}-\mathrm{M}$ of the test samples was significantly higher $(p<$ 0.05) than that of the control sample (Fig. 3e).

\section{Percentage inhibition/activation of poly-dHbS-M in the presence of fractionated leaf extracts}

Table 2 showed the percentage inhibition/activation of poly-dHbS-M in the presence of varying concentrations 

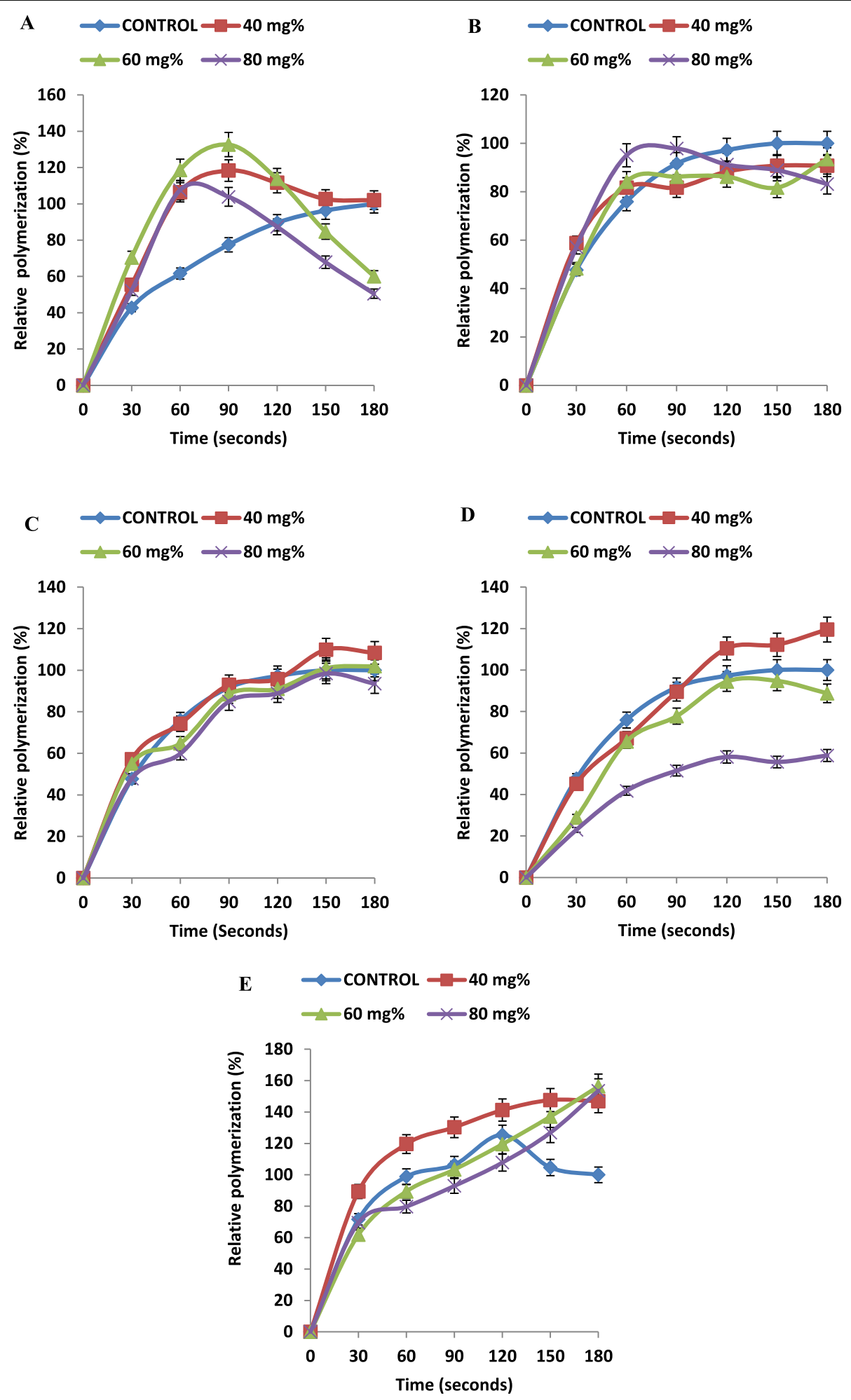

Fig. 3 Comparative levels of poly-dHbS-M of control sample and in the presence of fractionated leaf extracts of T. catappa. a Petroleum ether. $\mathbf{b}$ $n$-hexane. c Chloroform. d Ethylacetate. e Residual aqueous; $\mathrm{mg} \%=\mathrm{mg} / 100 \mathrm{~mL}$ 
Table 2 Relative levels of inhibition/activation of poly-dHbS-M by fractionated leaf extracts of A. occidentale, P. guajava, and T. catappa

\begin{tabular}{|c|c|c|c|c|c|c|}
\hline \multirow{2}{*}{$\begin{array}{l}\text { [Extract } \\
\text { fraction] }\end{array}$} & \multicolumn{6}{|c|}{ Relative inhibition/activation of polymerization (\%) } \\
\hline & $30 \mathrm{~s}$ & $60 \mathrm{~s}$ & $90 \mathrm{~s}$ & $120 \mathrm{~s}$ & $150 \mathrm{~s}$ & $180 \mathrm{~s}$ \\
\hline \multicolumn{7}{|c|}{ A. occidentale petroleum ether } \\
\hline $40 \mathrm{mg} \%$ & $9.76 \pm 1.23$ & $4.83 \pm 0.73$ & $5.76 \pm 1.10$ & $0.25 \pm 0.05 \uparrow$ & $0.31 \pm 0.02 \uparrow$ & $1.06 \pm 0.02 \uparrow$ \\
\hline 60 mg\% & $1.74 \pm 0.02$ & $7.10 \pm 1.11$ & $14.57 \pm 1.12$ & $16.49 \pm 1.22$ & $18.39 \pm 1.11$ & $18.65 \pm 1.10$ \\
\hline 80 mg\% & $0.38 \pm 0.01$ & $11.68 \pm 0.89$ & $10.43 \pm 1.08$ & $0.66 \pm 0.01$ & $1.43 \pm 0.02 \uparrow$ & $2.60 \pm 0.88 \uparrow$ \\
\hline \multicolumn{7}{|c|}{ A. occidentale $n$-hexane } \\
\hline 40 mg\% & $3.70 \pm 0.04$ & $18.15 \pm 1.21$ & $2.96 \pm 0.03$ & $11.48 \pm 1.10 \uparrow$ & $28.52 \pm 2.80 \uparrow$ & $41.48 \pm 3.87 \uparrow$ \\
\hline $60 \mathrm{mg} \%$ & $7.77 \pm 1.56$ & $25.19 \pm 2.56$ & $7.04 \pm 1.16$ & $0.37 \pm 0.01 \uparrow$ & $15.19 \pm 1.80 \uparrow$ & $32.59 \pm 3.67 \uparrow$ \\
\hline 80 mg\% & $4.81 \pm 1.65$ & $18.52 \pm 2.01$ & $27.41 \pm 2.98$ & $18.51 \pm 2.07$ & $3.33 \pm 0.98$ & $9.26 \pm 1.67 \uparrow$ \\
\hline \multicolumn{7}{|c|}{ A. occidentale chloroform } \\
\hline 40 mg\% & $87.80 \pm 4.90 \uparrow$ & $59.83 \pm 5.91 \uparrow$ & $38.69 \pm 2.10 \uparrow$ & $31.25 \pm 2.20 \uparrow$ & $35.84 \pm 3.00 \uparrow$ & $38.69 \pm 4.01 \uparrow$ \\
\hline $60 \mathrm{mg} \%$ & $31.25 \pm 3.67 \uparrow$ & $29.17 \pm 3.23 \uparrow$ & $17.55 \pm 1.10 \uparrow$ & $20.24 \pm 1.90 \uparrow$ & $31.67 \pm 3.00 \uparrow$ & $29.76 \pm 2.67 \uparrow$ \\
\hline 80 mg\% & $16.97 \pm 2.88 \uparrow$ & $24.41 \pm 3.11 \uparrow$ & $46.43 \pm 3.56$ & $46.42 \pm 2.56$ & $32.31 \pm 2.54$ & $27.38 \pm 2.56$ \\
\hline \multicolumn{7}{|c|}{ A. occidentale ethylacetate } \\
\hline 40 mg\% & $51.11 \pm 4.98$ & $90.00 \pm 5.78$ & $94.07 \pm 6.98$ & $81.85 \pm 5.34$ & $82.96 \pm 4.87$ & $79.26 \pm 4.98$ \\
\hline $60 \mathrm{mg} \%$ & $38.51 \pm 2.80$ & $66.67 \pm 3.48$ & $67.04 \pm \pm 3.95$ & $52.96 \pm 3.01$ & $48.88 \pm 3.89$ & $43.71 \pm 2.69$ \\
\hline 80 mg\% & $13.33 \pm 1.80$ & $22.22 \pm 2.00$ & $5.18 \pm 1.01 \uparrow$ & $17.41 \pm 1.90 \uparrow$ & $31.85 \pm 2.50 \uparrow$ & $26.67 \pm 2.11 \uparrow$ \\
\hline \multicolumn{7}{|c|}{ A. occidentale residual aqueous } \\
\hline 40 mg\% & $36.64 \pm 3.00 \uparrow$ & $101.13 \pm 7.9 \uparrow$ & $160.61 \pm 8.9 \uparrow$ & $129.53 \pm 7.1 \uparrow$ & $87.03 \pm 4.10 \uparrow$ & $29.93 \pm 2.78$ \\
\hline 60 mg\% & $20.59 \pm 2.00 \uparrow$ & $119.63 \pm 9.7 \uparrow$ & $103.75 \pm 7.9 \uparrow$ & $98.44 \pm 5.40 \uparrow$ & $363.18 \pm 11.8$ & $612.46 \pm 15.9$ \\
\hline 80 mg\% & $9.28 \pm 1.76 \uparrow$ & $105.26 \pm 8.6 \uparrow$ & $120.11 \pm 8.9 \uparrow$ & $43.34 \pm 2.52$ & $210.72 \pm 10.7$ & $563.95 \pm 13.8$ \\
\hline \multicolumn{7}{|c|}{ P. guajava petroleum ether } \\
\hline 40 mg\% & $72.62 \pm 3.50 \uparrow$ & $73.22 \pm 2.89 \uparrow$ & $56.25 \pm 4.97 \uparrow$ & $67.86 \pm 3.55 \uparrow$ & $84.06 \pm 4.01 \uparrow$ & $103.27 \pm 7.4 \uparrow$ \\
\hline 60 mg\% & $63.10 \pm 4.10 \uparrow$ & $70.54 \pm 4.92 \uparrow$ & $51.48 \pm 3.87 \uparrow$ & $58.34 \pm 2.98 \uparrow$ & $67.69 \pm 4.91 \uparrow$ & $75.30 \pm 3.77 \uparrow$ \\
\hline 80 mg\% & $70.83 \pm 3.80 \uparrow$ & $75.16 \pm 3.78 \uparrow$ & $49.99 \pm 2.99 \uparrow$ & $40.48 \pm 3.32 \uparrow$ & $42.39 \pm 4.11 \uparrow$ & $58.93 \pm 4.54 \uparrow$ \\
\hline \multicolumn{7}{|c|}{ P. guajava $n$-hexane } \\
\hline 40 mg\% & $38.68 \pm 2.98$ & $38.31 \pm 3.00$ & $34.71 \pm 2.09$ & $28.33 \pm 2.98$ & $27.15 \pm 2.67$ & $27.54 \pm 2.67$ \\
\hline 60 mg\% & $16.00 \pm 1.76$ & $23.90 \pm 1.98$ & $25.54 \pm 1.77$ & $25.39 \pm 2.00$ & $25.79 \pm 2.08$ & $34.53 \pm 2.33$ \\
\hline 80 mg\% & $22.60 \pm 2.76$ & $28.56 \pm 2.78$ & $34.23 \pm 3.03$ & $43.94 \pm 3.66$ & $49.57 \pm 3.89$ & $51.73 \pm 4.03$ \\
\hline \multicolumn{7}{|c|}{ P. guajava chloroform } \\
\hline 40 mg\% & $1.10 \pm 0.09 \uparrow$ & $2.19 \pm 0.86 \uparrow$ & $5.37 \pm 0.98$ & $11.51 \pm 1.09$ & $23.72 \pm 2.04$ & $29.10 \pm 2.54$ \\
\hline 60 mg\% & $20.56 \pm 2.40 \uparrow$ & $7.64 \pm 0.99$ & $22.00 \pm 2.03$ & $25.87 \pm 1.78$ & $24.23 \pm 2 / 12$ & $19.59 \pm 2.03$ \\
\hline 80 mg\% & $14.81 \pm 1.10 \uparrow$ & $5.08 \pm 0.89 \uparrow$ & $10.42 \pm 1.21$ & $15.85 \pm 1.78$ & $23.13 \pm 2.21$ & $30.84 \pm 2.78$ \\
\hline \multicolumn{7}{|c|}{ P. guajava ethylacetate } \\
\hline $40 \mathrm{mg} \%$ & $4.31 \pm 0.09 \uparrow$ & $14.75 \pm 1.02$ & $31.03 \pm 2.45$ & $45.10 \pm 3.11$ & $55.01 \pm 3.08$ & $67.73 \pm 3.98$ \\
\hline 60 mg\% & $17.53 \pm 1.60 \uparrow$ & $11.84 \pm 1.22 \uparrow$ & $5.60 \pm 0.98 \uparrow$ & $8.59 \pm 1.12 \uparrow$ & $7.76 \pm 1.11 \uparrow$ & $5.68 \pm 0.93 \uparrow$ \\
\hline 80 mg\% & $9.93 \pm 1.02$ & $15.93 \pm 1.65$ & $31.07 \pm 2.34$ & $31.06 \pm 2.01$ & $31.32 \pm 2.33$ & $37.00 \pm 3.09$ \\
\hline \multicolumn{7}{|c|}{ P. guajava residual aqueous } \\
\hline 40 mg\% & $22.01 \pm 1.98$ & $16.46 \pm 1.56$ & $17.29 \pm 1.45$ & $17.57 \pm 1.87$ & $33.18 \pm 2.45 \uparrow$ & $69.53 \pm 5.34 \uparrow$ \\
\hline 60 mg\% & $18.38 \pm 1.78$ & $3.86 \pm 1.32$ & $3.54 \pm 0.89$ & $0.83 \pm 0.08$ & $57.40 \pm 2.78 \uparrow$ & $100.73 \pm 8.8 \uparrow$ \\
\hline 80 mg\% & $8.08 \pm 0.78 \uparrow$ & $14.82 \pm 1.78 \uparrow$ & $12.84 \pm 1.04 \uparrow$ & $32.38 \pm 2.02 \uparrow$ & $100.53 \pm 8.5 \uparrow$ & $143.88 \pm 9.8 \uparrow$ \\
\hline \multicolumn{7}{|c|}{ T. catappa petroleum ether } \\
\hline 40 mg\% & $12.63 \pm 1.40 \uparrow$ & $44.78 \pm 3.59 \uparrow$ & $40.91 \pm 4.0 \uparrow$ & $22.06 \pm 2.11 \uparrow$ & $6.39 \pm 1.23 \uparrow$ & $2.02 \pm 0.21 \uparrow$ \\
\hline
\end{tabular}


Table 2 Relative levels of inhibition/activation of poly-dHbS-M by fractionated leaf extracts of A. occidentale, P. guajava, and T. catappa (Continued)

\begin{tabular}{|c|c|c|c|c|c|c|}
\hline \multirow{2}{*}{$\begin{array}{l}\text { [Extract } \\
\text { fraction] }\end{array}$} & \multicolumn{6}{|c|}{ Relative inhibition/activation of polymerization (\%) } \\
\hline & $30 \mathrm{~s}$ & $60 \mathrm{~s}$ & $90 \mathrm{~s}$ & $120 \mathrm{~s}$ & $150 \mathrm{~s}$ & $180 \mathrm{~s}$ \\
\hline $60 \mathrm{mg} \%$ & $27.61 \pm 2.20 \uparrow$ & $57.07 \pm \pm 4.78 \uparrow$ & $55.22 \pm 5.2 \uparrow$ & $24.25 \pm 2.19 \uparrow$ & $11.62 \pm 1.05$ & $39.90 \pm 2.56$ \\
\hline 80 mg\% & $9.43 \pm 0.56 \uparrow$ & $45.96 \pm 4.98 \uparrow$ & $26.43 \pm 3.1 \uparrow$ & $2.18 \pm 0.09$ & $28.46 \pm 1.45$ & $49.50 \pm 3.67$ \\
\hline \multicolumn{7}{|c|}{ T. catappa n-hexane } \\
\hline 40 mg\% & $11.07 \pm 1.9 \uparrow$ & $5.81 \pm 1.09 \uparrow$ & $9.91 \pm 1.08$ & $8.88 \pm 0.95$ & $9.21 \pm 0.17$ & $9.21 \pm 0.95$ \\
\hline 60 mg\% & $0.61 \pm 0.03 \uparrow$ & $8.23 \pm 0.85 \uparrow$ & $5.41 \pm 0.09$ & $11.00 \pm 0.87$ & $18.31 \pm 2.01$ & $6.50 \pm 0.98$ \\
\hline 80 mg\% & $9.46 \pm 0.97 \uparrow$ & $19.16 \pm 1.56 \uparrow$ & $6.21 \pm 1.54 \uparrow$ & $5.99 \pm 1.04$ & $15.06 \pm 1.67$ & $16.81 \pm 2.45$ \\
\hline \multicolumn{7}{|c|}{ T. catappa chloroform } \\
\hline 40 mg\% & $9.46 \pm 1.06 \uparrow$ & $0.96 \pm 0.02$ & $1.35 \pm 0.08 \uparrow$ & $1.46 \pm 0.09$ & $9.87 \pm 0.89 \uparrow$ & $8.33 \pm 1.02 \uparrow$ \\
\hline 60 mg\% & $7.29 \pm 0.09 \uparrow$ & $11.13 \pm 1.78$ & $3.18 \pm 0.45$ & $1.46 \pm 0.06$ & $0.09 \pm 0.001 \uparrow$ & $1.89 \pm 0.08 \uparrow$ \\
\hline 80 mg\% & $0.19 \pm 0.09 \uparrow$ & $16.02 \pm 1.98$ & $6.64 \pm 1.07$ & $8.32 \pm 1.44$ & $1.57 \pm 0.07$ & $6.44 \pm 0.98$ \\
\hline \multicolumn{7}{|c|}{ T. catappa ethylacetate } \\
\hline 40 mg\% & $2.53 \pm 0.88$ & $8.91 \pm 1.05$ & $2.05 \pm 0.18$ & $13.23 \pm 2.01 \uparrow$ & $12.21 \pm 1.05 \uparrow$ & $19.55 \pm 2.011$ \\
\hline 60 mg\% & $18.76 \pm 1.78$ & $10.34 \pm 0.98$ & $13.85 \pm 0.88$ & $2.74 \pm 0.31$ & $5.23 \pm 0.55$ & $11.22 \pm 0.67$ \\
\hline 80 mg\% & $24.72 \pm 2.01$ & $34.13 \pm 2.02$ & $40.13 \pm 3.11$ & $39.11 \pm 2.11$ & $44.33 \pm 3.02$ & $41.19 \pm 2.67$ \\
\hline \multicolumn{7}{|c|}{ T. catappa residual aqueous } \\
\hline 40 mg\% & $17.69 \pm 1.6 \uparrow$ & $22.80 \pm 1.01 \uparrow$ & $23.82 \pm 1.2 \uparrow$ & $15.83 \pm 0.78 \uparrow$ & $42.94 \pm 3.18 \uparrow$ & $46.95 \pm 3.551$ \\
\hline 60 mg\% & $9.91 \pm 1.03$ & $7.39 \pm 0.98$ & $3.07 \pm 0.56$ & $5.91 \pm 0.76$ & $32.43 \pm 3.67 \uparrow$ & $56.38 \pm 4.011$ \\
\hline 80 mg\% & $2.19 \pm 0.86$ & $17.09 \pm 1.56$ & $13.51 \pm 1.11$ & $17.61 \pm 1.14$ & $22.17 \pm 1.45 \uparrow$ & $53.56 \pm 3.861$ \\
\hline
\end{tabular}

The results are mean $(X) \pm$ S.D of three $(n=3)$ determinations; $\mathrm{mg} \%=\mathrm{mg} / 100 \mathrm{~mL}$

$\uparrow$ : Activation of poly-dHbS-M

of fractionated leaf extracts of A. occidentale, P. guajava, and $T$. catappa. Within the experimental time range of 0 $\mathrm{s} \leq t \leq 180 \mathrm{~s}, 60 \mathrm{mg} / 100 \mathrm{~mL}$ petroleum ether extract of A. occidentale caused an increasing level of inhibition of poly-dHbS-M as the experimental time progressed. Table 2 showed that 40 and $80 \mathrm{mg} / 100 \mathrm{~mL}$ petroleum ether extracts of $A$. occidentale inhibited poly-dHbS-M at $t<90 \mathrm{~s}$ and $t<120 \mathrm{~s}$ respectively. Further increase in the experimental time showed that 40 and $60 \mathrm{mg} / 100$ $\mathrm{mL}$ petroleum ether extracts of $A$. occidentale activated poly-dHbS-M. Among the three concentrations of petroleum ether extracts of $A$. occidentale, that of $60 \mathrm{mg} /$ $100 \mathrm{~mL}$ concentration exhibited the highest capacity to inhibit poly-dHbS-M; specifically at $t=180 \mathrm{~s}$; inhibition of poly-dHbS-M $=18.65 \pm 1.10 \%$ (Table 2 ).

The capacity of $40 \mathrm{mg} / 100 \mathrm{~mL} n$-hexane extract to inhibit poly-dHbS-M ranged between $2.96 \pm 0.03 \%$ at $t=$ $90 \mathrm{~s}$ and18.15 $\pm 1.21 \%$ at $t=60 \mathrm{~s}$ (Table 2). Similarly, 60 $\mathrm{mg} / 100 \mathrm{~mL} n$-hexane extract of $A$. occidentale inhibited poly-dHbS-M within the range of $7.04 \pm 1.16 \%$ at $t=90$ $\mathrm{s}$ and $25.19 \pm 2.56 \%$ at $t=60 \mathrm{~s}$. The highest capacity of $n$-hexane extract of $A$. occidentale to inhibit poly-dHbS$\mathrm{M}$ was registered in the presence of $80 \mathrm{mg} / 100 \mathrm{~mL}$ of the extract, which corresponded to $27.41 \pm 2.98 \%$ at $t=$ $90 \mathrm{~s}$. Conversely, 40 and $60 \mathrm{mg} / 100 \mathrm{~mL} n$-hexane extracts of $A$. occidentale activated poly-dHbS-M at $t>90$ $\mathrm{s}$, whereas $80 \mathrm{mg} / 100 \mathrm{~mL} n$-hexane extract of $A$. occidentale activated poly-dHbS-M at $t=180 \mathrm{~s}$; activation of poly-dHbS-M was $9.26 \pm 1.67 \%$ (Table 2 ).

Within the experimental time, 40 and $60 \mathrm{mg} / 100 \mathrm{~mL}$ chloroform extracts of $A$. occidentale activated poly$\mathrm{dHbS}-\mathrm{M}$ and were in the range of $31.25 \pm 2.2-87.80 \pm$ $4.90 \%$ and $17.55 \pm 1.1-31.67 \pm 3.0 \%$ respectively. Additionally, at $t<60 \mathrm{~s}, 80 \mathrm{mg} / 100 \mathrm{~mL}$ chloroform extract of $A$. occidentale activated poly-dHbS-M. Further increase in experimental time, $t>60 \mathrm{~s}, 80 \mathrm{mg} / 100 \mathrm{~mL}$ chloroform extract of $A$. occidentale inhibited poly$\mathrm{dHbS}-\mathrm{M}$ in the range of $27.38 \pm 2.56-46.43 \pm 3.56 \%$ (Table 2).

Table 2 showed that 40 and $60 \mathrm{mg} / 100 \mathrm{~mL}$ ethylacetate extracts of $A$. occidentale inhibited poly-dHbS-M within the experimental time. The $80 \mathrm{mg} / 100 \mathrm{~mL}$ ethylacetate extract inhibited poly-dHbS-M at $t<60 \mathrm{~s}$, whereas further increase in experimental time, $t>60 \mathrm{~s}$, caused activation of poly-dHbS-M in the range of $5.18 \pm$ $1.01-31.85 \pm 2.5 \%$.

Table 2 showed that $40 \mathrm{mg} / 100 \mathrm{~mL}$ residue aqueous extract of $A$. occidentale exhibited decreasing capacity to activate poly-dHbS-M. At $t=180 \mathrm{~s}, 40 \mathrm{mg} / 100 \mathrm{~mL}$ residual aqueous extract of $A$. occidentale inhibited poly$\mathrm{dHbS}-\mathrm{M}$ by $29.93 \pm 2.78 \%$. Furthermore, 60 and $80 \mathrm{mg} /$ $100 \mathrm{~mL}$ residual aqueous extracts of $A$. occidentale 
inhibited poly-dHbS-M at $t>150 \mathrm{~s}$ and $t>120 \mathrm{~s}$ respectively. Polymerization of deoxygenated sickle hemoglobin molecules (poly-dHbS-M) was activated in the presence of 40,60 , and $80 \mathrm{mg} / 100 \mathrm{~mL}$ petroleum ether extracts of $P$. guajava within the experimental time. Specifically, the stated concentrations of petroleum ether extracts of $P$. guajava activated poly-dHbS-M in the following corresponding range of values: $(40 \mathrm{mg} / 100$ $\mathrm{mL}) 56.25 \pm 4.97-103.27 \pm 7.4 \%$, $(60 \mathrm{mg} / 100 \mathrm{~mL}) 51.48$ $\pm 3.87-75.30 \pm 3.77 \%$, and $(80 \mathrm{mg} / 100 \mathrm{~mL}) 40.48 \pm$ $3.32-75.16 \pm 3.78 \%$ (Table 2).

The $n$-hexane extract of $P$. guajava inhibited poly$\mathrm{dHbS}-\mathrm{M}$ in a concentration-depended manner as the experimental time progressed. Table 2 showed that $40 \mathrm{mg} /$ $100 \mathrm{~mL} n$-hexane extract of $P$. guajava exhibited a decreasing capacity to inhibit poly-dHbS-M, whereas 80 $\mathrm{mg} / 100 \mathrm{~mL} n$-hexane extract of $P$. guajava showed increasing capacity to inhibit poly-dHbS-M with increasing experimental time. The capacity of $40 \mathrm{mg} / 100 \mathrm{~mL} n$ hexane extract of $P$. guajava to inhibit poly-dHbS-M peaked at $t=30 \mathrm{~s}$; inhibition of poly-dHbS-M was 38.68 $\pm 2.98 \%$. Peak inhibition in the presence of $80 \mathrm{mg} / 100$ $\mathrm{mL} n$-hexane extract of $P$. guajava was at $t=180 \mathrm{~s}$; inhibition of poly-dHbS-M was $51.73 \pm 4.03 \%$, whereas that of $60 \mathrm{mg} / 100 \mathrm{~mL}$ of the extract was at $t=180 \mathrm{~s}$; inhibition of poly-dHbS-M was $34.53 \pm 2.33 \%$ (Table 2).

The chloroform extract of P. guajava activated poly$\mathrm{dHbS}-\mathrm{M}$ at $t=30 \mathrm{~s}$. However, as the experimental time progressed, $t>30 \mathrm{~s}$, the chloroform extract of $P$. guajava inhibited poly-dHbS-M in a time-dependent manner. Specifically, Table 2 showed that $80 \mathrm{mg} / 100 \mathrm{~mL}$ chloroform extract caused the highest inhibition (38.84 \pm $2.78 \%)$ against poly-dHbS-M.

Table 2 showed that ethylacetate extract of $P$. guajava exhibited the highest capacity to inhibit poly-dHbS-M among the three ethylacetate extract concentrations. Conversely, poly-dHbS-M was activated by $60 \mathrm{mg} / 100$ $\mathrm{mL}$ ethylacetate extract of $P$. guajava throughout the experimental time. Poly-dHbS-M was inhibited by $80 \mathrm{mg} /$ $100 \mathrm{~mL}$ of ethylacetate extract of $P$. guajava within the range of $9.93 \pm 1.02-37.00 \pm 3.09 \%$ (Table 2).

Table 2 showed that 40 and $60 \mathrm{mg} / 100 \mathrm{~mL}$ residual aqueous extracts of $P$. guajava inhibited poly-dHbS-M within the time range of $0 \mathrm{~s} \leq t \leq 120 \mathrm{~s}$. Further increase in the experimental time, $t>120 \mathrm{~s}, 40$, and $60 \mathrm{mg} / 100 \mathrm{~mL}$ residual aqueous extracts of $P$. guajava activated poly$\mathrm{dHbS}-\mathrm{M}$ in a concentration-depended manner (Table 2). Notably, $80 \mathrm{mg} / 100 \mathrm{~mL}$ residual aqueous extract of $P$. guajava caused activation of dHbS-M throughout the experimental time. Peak activation of poly-dHbS-M (143.88 $\pm 9.8 \%$ ) occurred at $t=180 \mathrm{~s}$ in the presence of residual aqueous extract of $P$. guajava (Table 2).

Table 2 showed that 40,60, and $80 \mathrm{mg} / 100 \mathrm{~mL}$ petroleum ether extracts of $T$. catappa caused activation of
poly-dHbS-M within the experimental time range of $0 \mathrm{~s} \leq t$ $\leq 120 \mathrm{~s}$. Peak activation of poly-dHbS-M $(57.07 \pm 4.78 \%)$ was registered in the presence of $60 \mathrm{mg} / 100 \mathrm{~mL}$ petroleum ether extract of $T$. catappa at $t=60 \mathrm{~s}$. Further increase in experimental time, $t>120 \mathrm{~s}$, showed that 60 and $80 \mathrm{mg} /$ $100 \mathrm{~mL}$ petroleum ether extracts of T. catappa inhibited poly-dHbS-M in a time-depended manner. However, 40 $\mathrm{mg} / 100 \mathrm{~mL}$ petroleum ether extract of $T$. catappa activated poly-dHbS-M throughout the experimental time.

Within the experimental time, $t<60 \mathrm{~s}, 40,60$, and 80 $\mathrm{mg} / 100 \mathrm{~mL} n$-hexane extracts of $T$. catappa activated poly-dHbS-M (Table 2). Notably, $80 \mathrm{mg} / 100 \mathrm{~mL} n$-hexane extract of T. catappa caused maximum activation of poly$\mathrm{dHbS}-\mathrm{M}$ at $t=60 \mathrm{~s}$; activation of poly-dHbS-M was 19.16 $\pm 1.56 \%$. Conversely, Table 2 showed that 40 and $60 \mathrm{mg} /$ $100 \mathrm{~mL} n$-hexane extracts of T. catappa inhibited poly$\mathrm{dHbS}-\mathrm{M}$, whereas $80 \mathrm{mg} / 100 \mathrm{~mL} n$-hexane extract caused activation at $t=90 \mathrm{~s}$. Further increase in the experimental time caused inhibition of poly-dHbS-M by 40,60 , and 80 $\mathrm{mg} / 100 \mathrm{~mL} n$-hexane extracts of $T$. catappa. Peak inhibition of poly-dHbS-M (18.3 $\pm 12.0 \%)$ by $60 \mathrm{mg} / 100 \mathrm{~mL}$ of $n$-hexane extract of $T$. catappa occurred at $t=120 \mathrm{~s}$.

A cursory look at Table 2 showed that peak inhibition of poly-dHbS-M by 40,60 , and $80 \mathrm{mg} / 100 \mathrm{~mL}$ chloroform extracts of $T$. catappa occurred at $t=60 \mathrm{~s}$, specifically, $0.98 \pm 0.02 \%, 11.13 \pm 1.78 \%$, and $16.02 \pm 1.98 \%$ respectively. Further increase in experimental time, $t>$ $60 \mathrm{~s}$, showed diminishing capacity of the extract to inhibit poly-dHbS-M. Additionally, $40 \mathrm{mg} / 100 \mathrm{~mL}$ chloroform extract of $T$. catappa activated poly-dHbS-M except at $t=60 \mathrm{~s}$ and $t=120 \mathrm{~s}$.

Table 2 showed that 60 and $80 \mathrm{mg} / 100 \mathrm{~mL}$ ethylacetate extracts of $T$. catappa inhibited poly-dHbS-M within the experimental time with peak value at $t=30 \mathrm{~s}$; inhibition of polymerization was $18.76 \pm 1.78 \%$ and at $t$ $=90 \mathrm{~s}$; inhibition of polymerization was $40.13 \pm 3.11 \%$ respectively. However, $40 \mathrm{mg} / 100 \mathrm{~mL}$ ethylacetate extract of $T$. catappa inhibited poly-dHbS-M within the experimental time; at $t<90 \mathrm{~s}$. Further increase in experimental time caused activation of poly-dHbS-M by 40 $\mathrm{mg} / 100 \mathrm{~mL}$ ethylacetate extract of $T$. catappa (Table 2 ).

At the given experimental time range of $0 \mathrm{~s} \leq t \leq 180 \mathrm{~s}, 40$ $\mathrm{mg} / 100 \mathrm{~mL}$ residue aqueous extract of T. catappa activated poly-dHbS-M with a peak value at $t=180 \mathrm{~s}$; activation of poly-dHbS-M was $46.92 \pm 3.55 \%$ (Table 2). Conversely, 60 and $80 \mathrm{mg} / 100 \mathrm{~mL}$ residual aqueous extracts of T. catappa inhibited poly-dHbS-M within the experimental time of $t<$ $120 \mathrm{~s}$. Further increase in experimental time caused activation of poly-dHbS-M (Table 2).

\section{$\mathrm{RCPI} \%$ of $\mathrm{dHbS}-\mathrm{M}$ in the presence of fractionated leaf extracts}

Table 3 showed the RCPI\% of $\mathrm{dHbS}-\mathrm{M}$ in the presence of fractionated leaf extracts of A. occidentale, P. guajava, 
Table 3 Cumulative inhibition/activation of poly-dHbS-M by fractionated leaf extracts of A. occidentale, P. guajava, and T. catappa

\begin{tabular}{|c|c|c|c|c|}
\hline \multirow[t]{2}{*}{ Extract fraction } & \multicolumn{4}{|c|}{ AUC $\times 10^{3}$ (\%.second)/RCPI (\%) } \\
\hline & Control & $40 \mathrm{mg} \%$ & $60 \mathrm{mg} \%$ & 80 mg\% \\
\hline \multicolumn{5}{|l|}{ A. occidentale } \\
\hline Petroleum ether & $15.12 \pm 2.08^{\mathrm{a}}(100)$ & $14.54 \pm 2.57^{\mathrm{a}, \mathrm{b}}(3.8)$ & $13.09 \pm 8.32^{c, d}(13.4)$ & $13.51 \pm 6.53^{\mathrm{a}, \mathrm{b}, \mathrm{c}}(10.7)$ \\
\hline$n$-hexane & $22.21 \pm 1.48^{\mathrm{a}, \mathrm{b}}(100)$ & $23.29 \pm 10.33^{\mathrm{a}}(4.9) \uparrow$ & $21.97 \pm 11.34^{\mathrm{a}, \mathrm{b}, \mathrm{c}}(1.1)$ & $20.17 \pm 9.61^{c, d}(9.2)$ \\
\hline Chloroform & 22. $36 \pm 2.02^{c}(100)$ & $30.54 \pm 16.59^{\mathrm{a}}(36.6) \uparrow$ & $26.71 \pm 7.09^{\mathrm{a}, \mathrm{b}}(19.5) \uparrow$ & $19.44 \pm 7.17^{d}(13.1)$ \\
\hline Ethylacetate & $22.21 \pm 1.48^{\mathrm{a}, \mathrm{b}}(100)$ & $9.02 \pm 5.54^{d}(59.4)$ & $13.33 \pm 4.39^{c}(40.0)$ & $23.18 \pm 14.34^{\mathrm{a}}(4.4) \uparrow$ \\
\hline Residual aqueous & $16.65 \pm 2.00^{d}(100)$ & $31.65 \pm 9.00^{\complement}(90.1) \uparrow$ & $93.78 \pm 6.35^{\mathrm{a}}(463.2) \neq$ & $52.12 \pm 19.87^{\mathrm{b}}(213.0) \neq$ \\
\hline \multicolumn{5}{|l|}{ P. guajava } \\
\hline Petroleum ether & $22.36 \pm 2.02^{d}(100)$ & $34.53 \pm 14.00^{\mathrm{a}}(54.4) \uparrow$ & $32.83 \pm 12.82^{\mathrm{a}, \mathrm{b}}(46.8) \uparrow$ & $31.62 \pm 16.78^{\mathrm{a}, \mathrm{b}, \mathrm{c}}(41.4) \uparrow$ \\
\hline n-hexane & $15.12 \pm 2.08^{\mathrm{a}}(100)$ & $9.69 \pm 4.00^{\mathrm{b}, \mathrm{c}}(35.9)$ & $10.99 \pm 3.10^{b}(27.3)$ & $8.98 \pm 2.24^{\mathrm{b}, c, d}(40.6)$ \\
\hline Chloroform & $15.12 \pm 2.08^{\mathrm{a}}(100)$ & $13.56 \pm 1.45^{\mathrm{b}, \mathrm{c}}(10.3)$ & $13.05 \pm 9.63^{b, c, d}(13.7)$ & $13.77 \pm 2.94^{\mathrm{b}}(8.9)$ \\
\hline Ethylacetate & $15.12 \pm 2.08^{\mathrm{b}}(100)$ & $9.86 \pm 3.69^{c, d}(34.8)$ & $16.74 \pm 10.00^{\mathrm{a}}(10.7) \uparrow$ & $10.99 \pm 3.14^{c}(27.3)$ \\
\hline Residual aqueous & $16.65 \pm 2.00^{\complement}(100)$ & $16.49 \pm 3.26^{\mathrm{c,d}}(1.0)$ & $19.09 \pm 3.95^{\mathrm{b}}(14.7) \uparrow$ & $23.87 \pm 1.35^{\mathrm{a}}(43.4) \uparrow$ \\
\hline \multicolumn{5}{|l|}{ T. catappa } \\
\hline Petroleum ether & $12.53 \pm 2.11^{c, d}(100)$ & $16.36 \pm 5.88^{\mathrm{a}, \mathrm{b}}(30.6) \uparrow$ & $16.51 \pm 5.07^{\mathrm{a}}(31.8) \uparrow$ & $13.32 \pm 3.25^{\complement}(6.3) \uparrow$ \\
\hline n-hexane & $13.85 \pm 5.93^{\mathrm{a}, \mathrm{b}}(100)$ & $13.40 \pm 5.29^{a, b, c}(3.3)$ & $13.00 \pm 6.80^{\mathrm{a}, \mathrm{b}, \mathrm{c}, \mathrm{d}}(6.1)$ & $14.03 \pm 1.09^{\mathrm{a}}(1.3) \uparrow$ \\
\hline Chloroform & $13.85 \pm 5.92^{\mathrm{a}, \mathrm{b}}(100)$ & $14.37 \pm 2.02^{\mathrm{a}}(3.8) \uparrow$ & $13.53 \pm 2.00^{\mathrm{a}, \mathrm{b}, \mathrm{c}}(2.3)$ & $12.81 \pm 1.98^{c, \mathrm{~d}}(7.5)$ \\
\hline Ethylacetate & $13.85 \pm 5.92^{a, b}(100)$ & $14.52 \pm 1.32^{\mathrm{a}}(4.8) \uparrow$ & $12.18 \pm 3.48^{\complement}(12.1)$ & $7.78 \pm 2.12^{d}(43.8)$ \\
\hline Residual aqueous & $16.65 \pm 2.00^{b, c}(100)$ & $21.05 \pm 1.08^{\mathrm{a}}(26.4) \uparrow$ & $17.68 \pm 6.75^{b}(6.2) \uparrow$ & $16.61 \pm 5.00^{\mathrm{b}, \mathrm{c}, \mathrm{d}}(0.2)$ \\
\hline
\end{tabular}

The mean $(X) \pm$ S.D of three $(n=3)$ determinations; $\mathrm{mg} \%=\mathrm{mg} / 100 \mathrm{~mL}$. Means in the row with the same letter are not significantly different at $p>0.05$ according to $\mathrm{LSD}$ $\uparrow$ : Cumulative activation of poly-dHbS-M

‡: RCPI\% ${ }_{\text {Test }}>$ RCPI\% ${ }_{\text {Control }}$

and T. catappa. The RCPI\% of $\mathrm{dHbS}-\mathrm{M}$ in the presence of fractionated leaf extract of $A$. occidentale varied within a wide range of $3.8-59.4 \%$ and was indicative of cumulative inhibition of poly-dHbS-M. Conversely, in the presence of $40 \mathrm{mg} / 100 \mathrm{~mL}$ residual aqueous extract of $A$. occidentale, RCPI\% was indicative of cumulative activation of poly-dHbS-M. Table 3 showed that RCPI\% of $\mathrm{dHbS}-\mathrm{M}$ in the presence 60 and $80 \mathrm{mg} / 100 \mathrm{~mL}$ residual aqueous extracts of $A$. occidentale were comparatively greater than that of the control sample. The RCPI\% of dHbS-M of the samples containing 40, 60, and $80 \mathrm{mg} / 100 \mathrm{~mL}$ petroleum ether extracts of $P$. guajava as well as $80 \mathrm{mg} / 100 \mathrm{~mL}$ residual aqueous extract of $P$. guajava were indicative of cumulative activation of poly$\mathrm{dHbS}-\mathrm{M}$ (Table 3). Additionally, the comparative raised level of RCPI\% of dHbS-M in the presence of $80 \mathrm{mg} / 100$ $\mathrm{mL} n$-hexane of $P$. guajava was indicative of higher capacity of the extract to cumulatively inhibit poly-dHbS-M than other concentrations of fractionated leaf extracts of P. guajava.

Table 3 showed that dHbS-M of the samples containing 60 and $80 \mathrm{mg} / 100 \mathrm{~mL}$ ethylacetate of $T$. catappa gave comparative raised levels of RCPI\% indicative of cumulative inhibition of poly-dHbS-M. RCPI\% of dHbS-M in the presence of 40 and $60 \mathrm{mg} / 100 \mathrm{~mL}$ petroleum ether extracts of $T$. catappa as well as $40 \mathrm{mg} / 100 \mathrm{~mL}$ residual aqueous extract of $T$. catappa were indicative of comparatively raised levels of cumulative activation of poly-dHbS-M.

The dHbS-M of the sample containing $40 \mathrm{mg} / 100 \mathrm{~mL}$ residual aqueous of $A$. occidentale gave $\mathrm{RCPI} \%=90.1$, which represented the maximum cumulative activation of poly-dHbS-M compared with other concentrations of fractionated leaf extracts of $A$. occidentale, P. guajava, and T. catappa.

The fractionated leaf extracts of $A$. occidentale, $P$. guajava, and T. catappa that exhibited comparatively high potency to inhibit poly-dHbS-M, summarized from Tables 2 and 3, were as follows: A. occidentale (petroleum ether and ethylacetate extracts), $P$. guajava ( $n$-hexane, chloroform, and ethylacetate extracts), and $T$. catappa (ethylacetate extract).

\section{Gas chromatograms of fractionated leaf extracts}

The gas chromatograms, indicating the peaks of eluted phytocomponents at corresponding time intervals, of the fractionated leaf extracts of A. occidentale, P. guajava, and $T$. catappa that exhibited comparatively high potency to inhibit poly-dHbS-M are illustrated in Fig. $4 \mathrm{a}-\mathrm{f}$.

Table 4(A-F) showed the combinations of phytocomponents from fractionated leaf extracts of $A$. occidentale, $P$. guajava, and $T$. catappa denoting their retention 


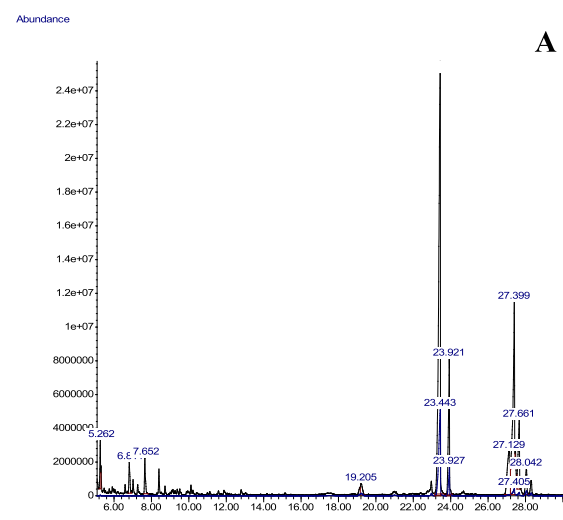

A

Abundance
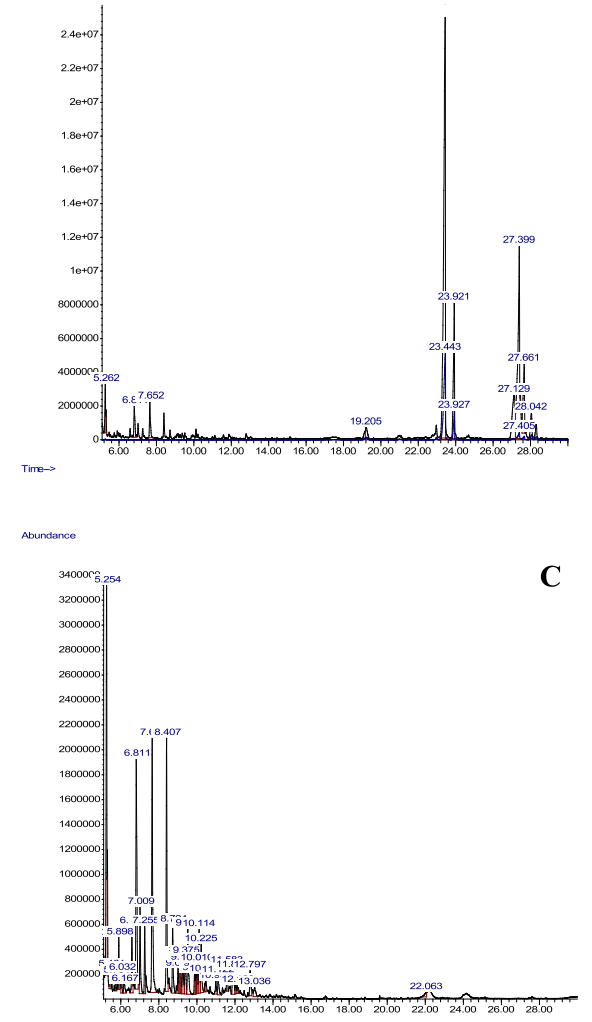

C Tima $\rightarrow$
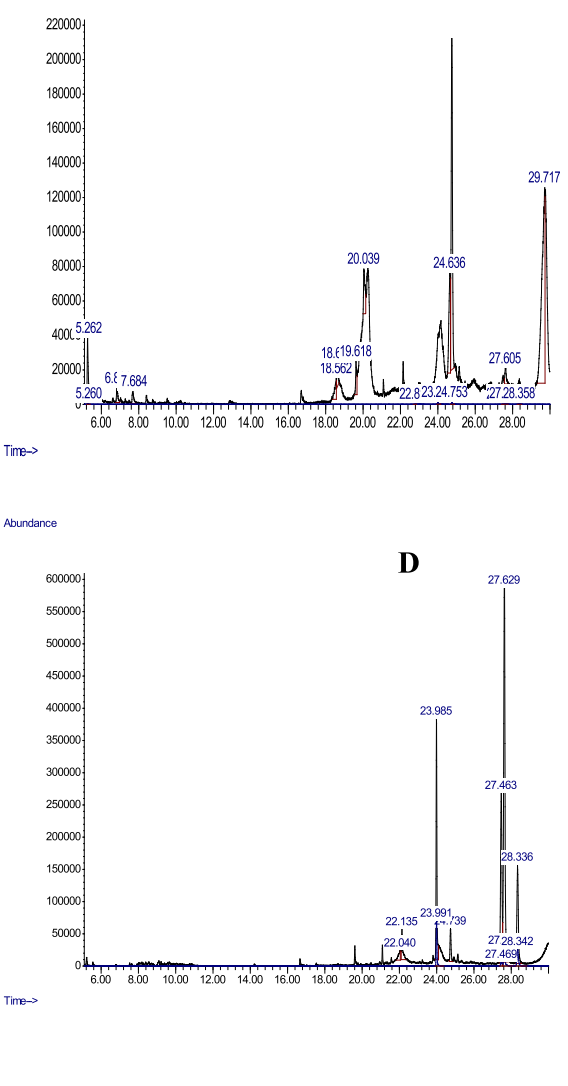

Abundance

$\mathbf{E}$
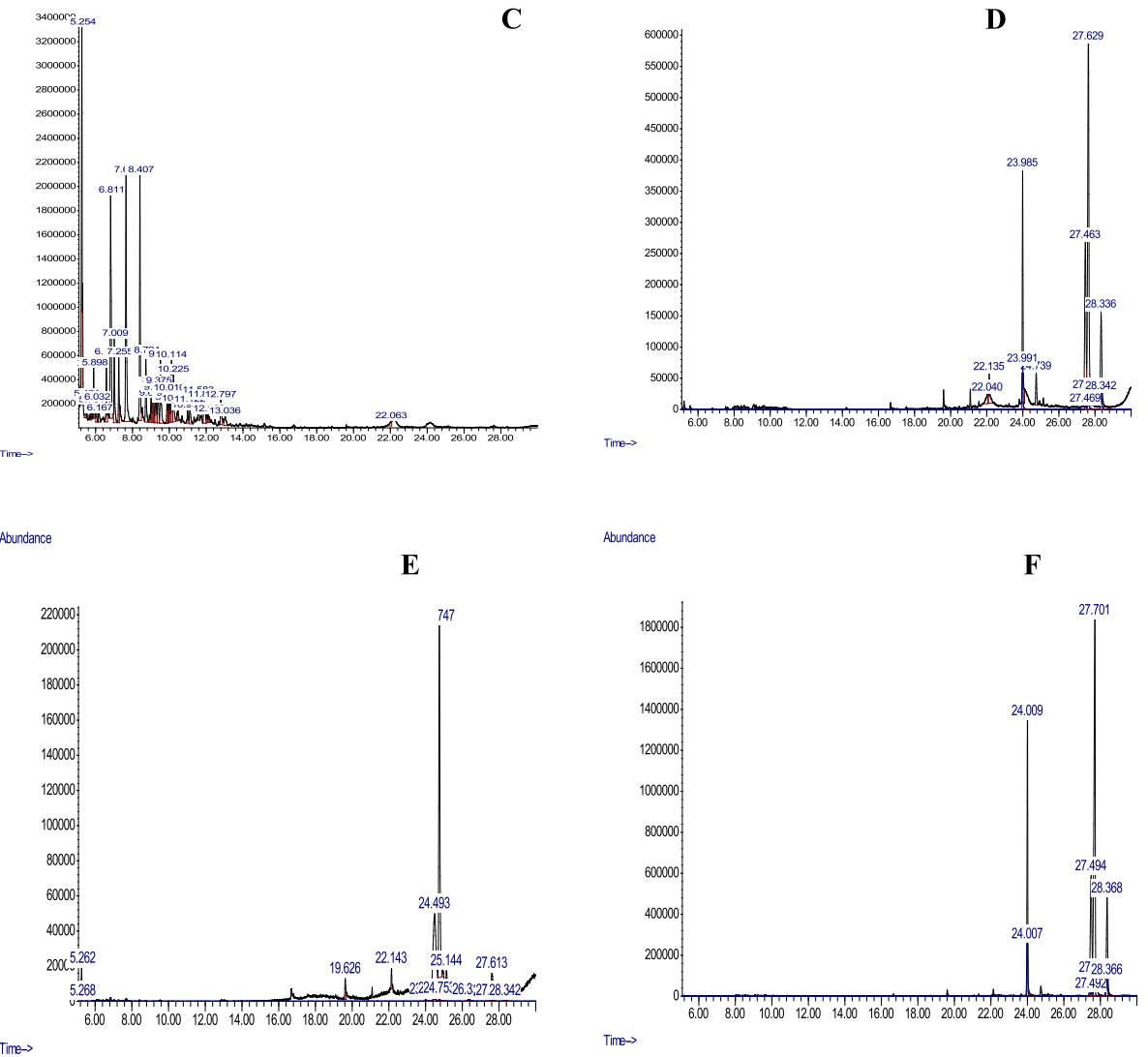

Fig. 4 GC-MS chromatograms. a Petroleum ether extract of A. occidentale. b Ethylacetate extract of A. occidentale. $\mathbf{c} n$-Hexane extract of $P$. guajava. d Chloroform extract of $P$. guajava. e Ethylacetate extract of $P$. guajava. $\mathbf{f}$ Ethylacetate extract of $T$. catappa

time, molecular formula, and weights as well as their relative abundance denoted as percentage of peak areas (\%PA) of the chromatograms. Also, the presence of aliphatic compounds in corresponding fractionated leaf extracts of $A$. occidentale, P. guajava, and T. catappa are summarized in Table 4(A-F).

In comparative terms, Table 4(A) showed that the major phytocomponents from petroleum ether extract of A. occidentale were hexadecanoic acid, methyl ester, 11- octadecenoic acid, and pentadecanoic acid-14-methyl, methyl ester. Likewise, pentacosane, dibutyl phthalate, and tricosane were the major phytocomponents from ethylacetate extract of A. occidentale (Table 4(B)). D-Erythro-sphinganine was the phytocomponent detected in appreciable quantity in $n$-hexane extract of $P$. guajava (Table $4(C)$ ). Additionally, the major phytocomponents from chloroform extract of $P$. guajava were 11octadecenoic acid, methyl ester, 9,11-octadecadienoic 
Table 4 Phytocomponents of (A) petroleum ether extract of A. occidentale, (B) ethylacetate extract of A. occidentale, (C) $n$-hexane extract of P. guajava, (D) chloroform extract of P. guajava, (E) ethylacetate extract of $P$. guajava, and (F) ethylacetate extract of $T$. catappa

\begin{tabular}{|c|c|c|c|c|c|}
\hline S/No. & $T_{R}(\min )$ & Phytocomponents & MF & $\mathrm{MW}(\mathrm{g} / \mathrm{mol})$ & $\% \mathrm{PA}$ \\
\hline \multicolumn{6}{|l|}{$\bar{A}$} \\
\hline 1. & 5.262 & o-Xylene & $\mathrm{C}_{6} \mathrm{H}_{4}\left(\mathrm{CH}_{3}\right)_{2}$ & 106.16 & 2.30 \\
\hline 2. & 6.811 & Benzene, 1-ethyl-4-methyl- & $\mathrm{C}_{9} \mathrm{H}_{12}$ & 120.19 & 2.13 \\
\hline 3. & 7.652 & Benzene, 1, 2, 4-trimethyl- & $\mathrm{C}_{9} \mathrm{H}_{12}$ & 120.19 & 2.33 \\
\hline 4. & 19.205 & Methyl tetradecanoate ${ }^{\beta}$ & $\mathrm{C}_{15} \mathrm{H}_{30} \mathrm{O}_{2}$ & 242.40 & 1.53 \\
\hline 5. & 23.437 & Hexadecanoic acid, methyl ester ${ }^{\ngtr}$ & $\mathrm{C}_{17} \mathrm{H}_{34} \mathrm{O}_{2}$ & 270.45 & 49.59 \\
\hline 6. & 23.921 & Pentadecanoic acid, 14-methyl-, methyl ester ${ }^{p}$ & $\mathrm{C}_{17} \mathrm{H}_{34} \mathrm{O}_{2}$ & 270.50 & 10.34 \\
\hline 7. & 27.129 & 9, 12-Octadecadienoic acid (Z, Z)-, methyl ester ${ }^{p}$ & $\mathrm{C}_{19} \mathrm{H}_{34} \mathrm{O}_{2}$ & 294.47 & 8.49 \\
\hline 8. & 27.399 & 11-Octadecenoic acid, methyl ester ${ }^{P}$ & $\mathrm{C}_{19} \mathrm{H}_{36} \mathrm{O}_{2}$ & 296.49 & 14.14 \\
\hline 9. & 27.661 & 9-Octadecenoic acid, methyl ester, (E)- ${ }^{P}$ & $\mathrm{C}_{19} \mathrm{H}_{36} \mathrm{O}_{2}$ & 296.49 & 6.52 \\
\hline 10. & 28.042 & Methyl stearate ${ }^{\ngtr}$ & $\mathrm{C}_{19} \mathrm{H}_{38} \mathrm{O}_{2}$ & 298.50 & 2.62 \\
\hline \multicolumn{6}{|l|}{ B } \\
\hline 1. & 5.262 & Benzene, 1, 3-dimethyl- & $\mathrm{C}_{8} \mathrm{H}_{10}$ & 106.17 & 3.97 \\
\hline 2. & 6.826 & 2, 4-Nonadiyne & $\mathrm{C}_{9} \mathrm{H}_{12}$ & 120.19 & 1.33 \\
\hline 3. & 7.684 & Benzene, (1-methylethyl)- & $\mathrm{C}_{9} \mathrm{H}_{12}$ & 120.19 & 1.31 \\
\hline 4. & 18.562 & Hexacosane $^{p}$ & $\mathrm{C}_{26} \mathrm{H}_{54}$ & 366.72 & 2.27 \\
\hline 5. & 18.617 & Methoxyacetic acid, 3-pentadecyl ester ${ }^{\nexists}$ & $\mathrm{C}_{18} \mathrm{H}_{36} \mathrm{O}_{3}$ & 300.50 & 1.71 \\
\hline 6. & 19.618 & 1-Hexacosanol ${ }^{\beta}$ & $\mathrm{C}_{26} \mathrm{H}_{54} \mathrm{O}$ & 382.70 & 2.38 \\
\hline 7. & 20.039 & Tetracosane $e^{\circledR}$ & $\mathrm{C}_{24} \mathrm{H}_{50}$ & 338.70 & 4.66 \\
\hline 8. & 22.817 & 2-Hexyl-1-octanol $\left.\right|^{\nexists}$ & $\mathrm{C}_{14} \mathrm{H}_{30} \mathrm{O}$ & 214.39 & $<0.01$ \\
\hline 9. & 24.001 & Diisooctyl phthalate ${ }^{p}$ & $\mathrm{C}_{24} \mathrm{H}_{38} \mathrm{O}_{4}$ & 390.60 & $<0.01$ \\
\hline 10. & 24.478 & Bicyclo [4.1.0] heptane-3-cyclopropyl-7-hydroxymethyl [cis] $]^{\nexists}$ & $\mathrm{C}_{11} \mathrm{H}_{18} \mathrm{O}$ & 166.26 & $<0.01$ \\
\hline 11. & 24.636 & Tricosane $e^{\nexists}$ & $\mathrm{C}_{23} \mathrm{H}_{48}$ & 324.60 & 10.55 \\
\hline 12. & 24.747 & Dibutyl phthalate & $\mathrm{C}_{16} \mathrm{H}_{22} \mathrm{O}_{4}$ & 278.34 & 29.34 \\
\hline 13. & 27.605 & Undec-10-ynoic acid, undecyl ester ${ }^{P}$ & $\mathrm{C}_{22} \mathrm{H}_{40} \mathrm{O}_{2}$ & 336.55 & 1.53 \\
\hline 14. & 27.629 & 3-Cyclopentylpropanoic acid, but-3-yn-2yl ester ${ }^{P}$ & $\mathrm{C}_{12} \mathrm{H}_{18} \mathrm{O}_{2}$ & 194.27 & $<0.01$ \\
\hline 15. & 28.360 & 4-Nonanol 2, 6, 8 trimethyl- ${ }^{P}$ & $\mathrm{C}_{12} \mathrm{H}_{26} \mathrm{O}$ & 186.33 & $<0.01$ \\
\hline 16. & 29.717 & Pentacosane $e^{\ngtr}$ & $\mathrm{C}_{25} \mathrm{H}_{52}$ & 352.70 & 40.95 \\
\hline \multicolumn{6}{|l|}{ C } \\
\hline 1. & 25.001 & D-Erythro-sphinganine $e^{\nexists}$ & $\mathrm{C}_{18} \mathrm{H}_{39} \mathrm{NO}_{2}$ & 525.00 & $<0.01$ \\
\hline \multicolumn{6}{|l|}{$\mathrm{D}$} \\
\hline 1. & 22.040 & Ethanol, 2-(dodecyloxy)- ${ }^{P}$ & $\mathrm{C}_{14} \mathrm{H}_{30} \mathrm{O}_{2}$ & 230.39 & 1.46 \\
\hline 2. & 22.135 & Tricosyl heptafluorobutyrate ${ }^{\nexists}$ & $\mathrm{C}_{27} \mathrm{H}_{47} \mathrm{~F}_{7} \mathrm{O}_{2}$ & 536.65 & 2.79 \\
\hline 3. & 23.993 & Hexadecanoic acid, methyl ester ${ }^{\nexists}$ & $\mathrm{C}_{17} \mathrm{H}_{34} \mathrm{O}_{2}$ & 270.45 & 5.63 \\
\hline 4. & 24.739 & Dibutyl phthalate & $\mathrm{C}_{16} \mathrm{H}_{22} \mathrm{O}_{4}$ & 278.34 & 2.85 \\
\hline 5. & 27.463 & 9, 11-Octadecadienoic acid, methyl ester, $(\mathrm{E}, \mathrm{E})^{-}{ }^{\circledR}$ & $\mathrm{C}_{19} \mathrm{H}_{34} \mathrm{O}_{2}$ & 294.47 & 19.52 \\
\hline 6. & 27.471 & 9, 12-Octadecadienoic acid [Z, Z], methyl ester ${ }^{p}$ & $\mathrm{C}_{19} \mathrm{H}_{34} \mathrm{O}_{2}$ & 294.47 & 5.64 \\
\hline 7. & 27.637 & Trans-13-octadecenoic acid, methyl ester ${ }^{\beta}$ & $\mathrm{C}_{19} \mathrm{H}_{36} \mathrm{O}_{2}$ & 296.49 & 5.62 \\
\hline 8. & 27.629 & 11-Octadecenoic acid, methyl ester ${ }^{p}$ & $\mathrm{C}_{19} \mathrm{H}_{36} \mathrm{O}_{2}$ & 296.49 & 44.49 \\
\hline 9. & 28.336 & Methyl stearate ${ }^{\ngtr}$ & $\mathrm{C}_{19} \mathrm{H}_{38} \mathrm{O}_{2}$ & 298.50 & 12.00 \\
\hline \multicolumn{6}{|l|}{$E$} \\
\hline 1. & 5.262 & Benzene, 1, 3-dimethyl- & $\mathrm{C}_{8} \mathrm{H}_{10}$ & 106.17 & 4.30 \\
\hline
\end{tabular}


Table 4 Phytocomponents of (A) petroleum ether extract of A. occidentale, (B) ethylacetate extract of A. occidentale, (C) $n$-hexane extract of P. guajava, (D) chloroform extract of P. guajava, (E) ethylacetate extract of $P$. guajava, and (F) ethylacetate extract of $T$. catappa (Continued)

\begin{tabular}{|c|c|c|c|c|c|}
\hline $\mathrm{S} / \mathrm{No}$. & $T_{R}(\min )$ & Phytocomponents & MF & $\mathrm{MW}(\mathrm{g} / \mathrm{mol})$ & $\% \mathrm{PA}$ \\
\hline 2. & 5.270 & p-Xylene & $\mathrm{C}_{8} \mathrm{H}_{10}$ & 106.16 & $<0.01$ \\
\hline 3. & 19.626 & 2-Tetradecanol $\left.\right|^{\beta}$ & $\mathrm{C}_{14} \mathrm{H}_{30} \mathrm{O}$ & 214.39 & 2.46 \\
\hline 4. & 22.143 & 5-Octadecene, (E)- & $\mathrm{C}_{18} \mathrm{H}_{36}$ & 252.48 & 1.91 \\
\hline 5. & 24.001 & Heptanoic acid, 3, 6, 6-trimethyl-methyl ester ${ }^{\beta}$ & $\mathrm{C}_{11} \mathrm{H}_{22} \mathrm{O}_{2}$ & 186.29 & $<0.01$ \\
\hline 6. & 24.485 & Methyl 12-hydroxy-9-octadecenoate ${ }^{p}$ & $\mathrm{C}_{19} \mathrm{H}_{36} \mathrm{O}_{3}$ & 312.50 & $<0.01$ \\
\hline 7. & 24.493 & 9-Octadecenoic acid, 12-hydroxy-, methyl ester, [R-(Z)]- & $\mathrm{C}_{19} \mathrm{H}_{36} \mathrm{O}_{3}$ & 312.49 & 29.32 \\
\hline 8. & 24.747 & Dibutyl phthalate $\mathrm{e}^{\circledR}$ & $\mathrm{C}_{16} \mathrm{H}_{22} \mathrm{O}_{4}$ & 278.34 & 56.52 \\
\hline 9. & 25.144 & 1-Dodecanol, 2-octyl- ${ }^{\ngtr}$ & $\mathrm{C}_{20} \mathrm{H}_{42} \mathrm{O}$ & 298.50 & 2.90 \\
\hline 10. & 26.335 & Oxiraneundecanoic acid, 3-pentyl-, methyl ester, cis $^{p}$ & $\mathrm{C}_{19} \mathrm{H}_{36} \mathrm{O}_{3}$ & 312.50 & $<0.01$ \\
\hline 11. & 27.470 & 1, 2-Cyclohexanediol, cyclic sulfite, cis ${ }^{\nexists}$ & $\mathrm{C}_{6} \mathrm{H}_{10} \mathrm{O}_{3} \mathrm{~S}$ & 162.21 & $<0.01$ \\
\hline 12. & 27.613 & 9-Octadecenoic acid (Z)-, methyl ester ${ }^{\beta}$ & $\mathrm{C}_{19} \mathrm{H}_{36} \mathrm{O}_{2}$ & 296.49 & 2.59 \\
\hline 13. & 27.621 & 1-Eicosanol $\left.\right|^{P}$ & $\mathrm{C}_{20} \mathrm{H}_{42} \mathrm{O}$ & 298.50 & $<0.01$ \\
\hline 14. & 28.344 & Methyl phosphonic acid, ethyl ester ${ }^{p}$ & $\mathrm{C}_{3} \mathrm{H}_{9} \mathrm{O}_{3} \mathrm{P}$ & 124.08 & $<0.01$ \\
\hline \multicolumn{6}{|l|}{$\mathrm{F}$} \\
\hline 1. & 24.009 & Hexadecanoic acid, methyl ester ${ }^{\beta}$ & $\mathrm{C}_{17} \mathrm{H}_{34} \mathrm{O}_{2}$ & 270.45 & 20.03 \\
\hline 2. & 27.494 & 9, 11-Octadecadienoic acid, methyl ester, (E, E)- ${ }^{\mathrm{P}}$ & $\mathrm{C}_{19} \mathrm{H}_{34} \mathrm{O}_{2}$ & 294.50 & 18.26 \\
\hline 3. & 27.701 & Trans-13-octadecenoic acid, methyl ester ${ }^{\circledR}$ & $\mathrm{C}_{19} \mathrm{H}_{36} \mathrm{O}_{2}$ & 296.49 & 49.49 \\
\hline 4. & 28.368 & Methyl stearate ${ }^{\ngtr}$ & $\mathrm{C}_{19} \mathrm{H}_{38} \mathrm{O}_{2}$ & 298.50 & 12.22 \\
\hline
\end{tabular}

acid, methyl ester, (E, E), and methyl stearate (Table 4(D)). Table 4(E) showed that the relative abundance of dibutyl phthalate and 9-octadecenoic acid-12-hydroxy-, methyl ester, $[\mathrm{R}-(\mathrm{Z})]$ - in ethylacetate extract of $P$. guajava was equivalent to $56.52 \% \mathrm{PA}$ and $29.32 \% \mathrm{PA}$ respectively. Ethylacetate extract of T. catappa contained four phytocomponents and their relative abundance equivalent to \%PA ranged between 12.22 and 49.49 (Table 4(F)).

\section{FT-IR spectra of fractionated leaf extracts}

Figure 5a-f showed FT-IR spectra of $A$. occidentale (petroleum ether and ethylacetate extracts), P. guajava (n-hexane, chloroform, and ethylacetate extracts), and $T$. catappa (ethylacetate extract) and summarized in Table 4(A-F). Petroleum ether extract of $A$. occidentale gave characteristic peaks depicting sp3 $\mathrm{C}-\mathrm{H}$ stretch within the range of 2955.8-2926.0 $\mathrm{cm}^{-1}$ (Table 4(A)). The $\mathrm{C}-\mathrm{H}$ stretch at $2855.1 \mathrm{~cm}^{-1}$ exhibited medium band and $\mathrm{C}-\mathrm{O}$ stretch at $1748.1 \mathrm{~cm}^{-1}$ exhibited weak band, which were indicative of the presence of molecular species containing aldehyde $(\mathrm{HC}=\mathrm{O})$ and ester carbonyl $(\mathrm{C}=\mathrm{O})$ functional groups. Additionally, ether $\mathrm{C}-\mathrm{O}$ stretch at $1036.2 \mathrm{~cm}^{-1}$ suggested the presence of alkoxy (X-O-C) functional group in petroleum ether extract of $A$. occidentale. The presence of conjugated alkenes in petroleum ether extract of $A$. occidentale was indicative of weak band at $1606.5 \mathrm{~cm}^{-1}$ and medium band at $1453.7 \mathrm{~cm}^{-1}$ were indicative of aromatic compound $\mathrm{C}=\mathrm{C}$ stretch (Fig. 5a). Petroleum ether extract of A. occidentale exhibited characteristic peaks within the range of (905.7693.3) $\mathrm{cm}^{-1}$, suggesting the presence of aromatic compounds in the fraction. The peaks at $1379.4 \mathrm{~cm}^{-1}$ and $1237.5 \mathrm{~cm}^{-1}$ indicated the presence of nitro-compounds and halide containing organic compounds (Table 4(A)).

Figure $5 \mathrm{~b}$ showed that ethylacetate extract of $\mathrm{A}$. occidentale exhibited characteristic broad band around $3444.1 \mathrm{~cm}^{-1}$, which was indicative of the presence of dimeric alcohol functional group $(\mathrm{O}-\mathrm{H})$ stretch (Table 4(B)). The fraction also exhibited alkanes sp3 (-C-H) stretch within the region of $(2989.1-2907.3) \mathrm{cm}^{-1}$ and alkenes sp2 $(=\mathrm{C}-\mathrm{H})$ bend at $(939.3-878.7) \mathrm{cm}^{-1}$. Likewise, Fig. 5b showed peak values within the range of (939.3-849.8) $\mathrm{cm}^{-1}$, which were indicative of the presence of unsaturated hydrocarbons, typified by alkenes sp2 $(=\mathrm{C}-\mathrm{H})$ bend and tri-substituted alkenes (= $\mathrm{C}-\mathrm{H})$ bend. The $\mathrm{C}-\mathrm{O}$ stretch within the regions of (1889.8-1654.9) $\mathrm{cm}^{-1}$ and $1376.9 \mathrm{~cm}^{-1}$ were indicative of the presence of carbonyl functional $(\mathrm{C}=\mathrm{O})$ and amide $\left(\mathrm{H}_{2} \mathrm{~N}-\mathrm{C}=\mathrm{O}\right)$ groups in ethylacetate extract of $A$. occidentale (Table 4(B)). Aromatic compounds in ethylacetate extract of $A$. occidentale exhibited $\mathrm{C}-\mathrm{H}$ bend at regions of 786.5 and $733.0 \mathrm{~cm}^{-1}$ (Table 4(B)).

Figure $5 \mathrm{c}$ showed that $n$-hexane extract of $P$. guajava exhibited alkanes sp3 $(-\mathrm{C}-\mathrm{H})$ stretch within the regions $(2955.8-2858.9) \mathrm{cm}^{-1}$ as well as alkenes $\mathrm{sp} 2 \mathrm{C}-\mathrm{H}$ bend 


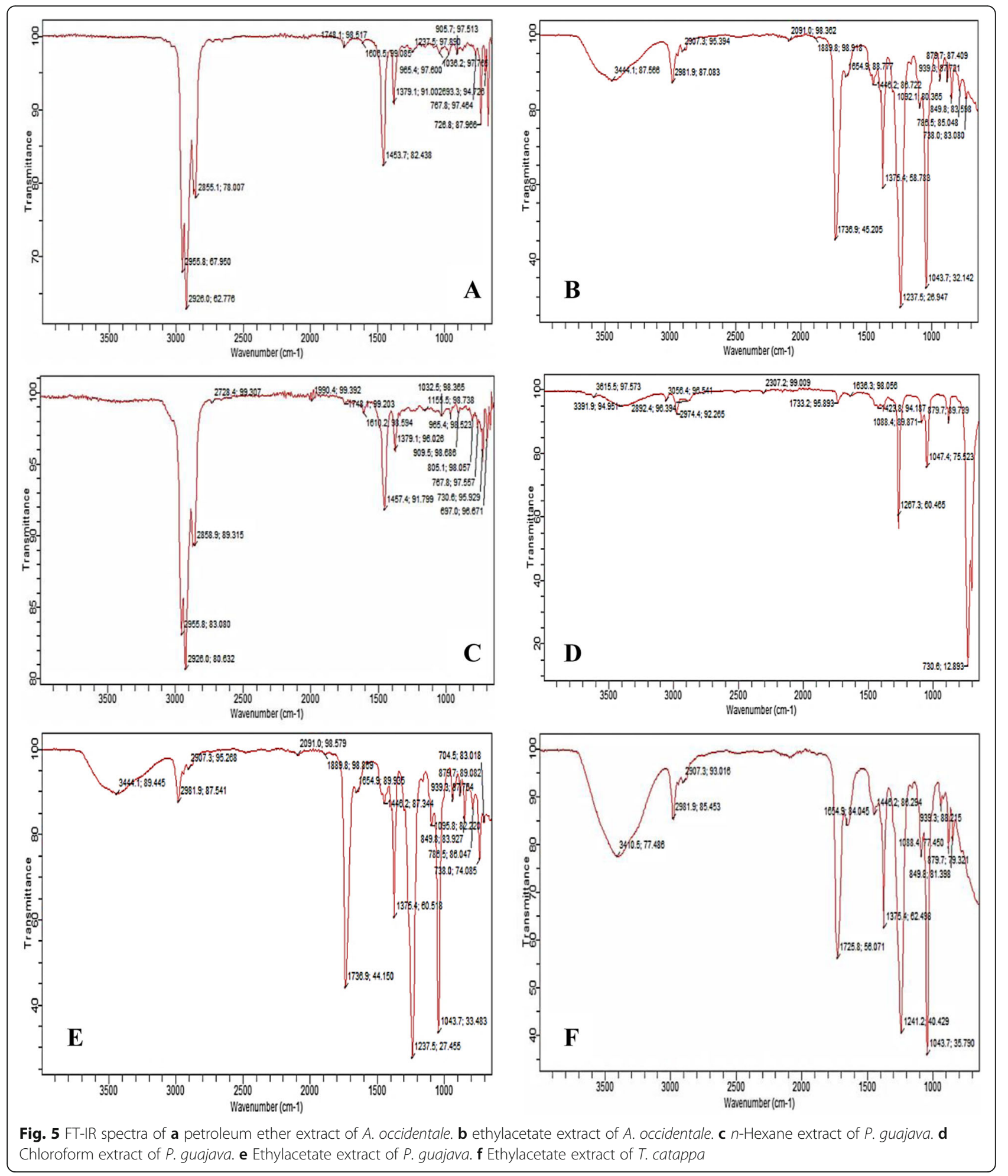

and aromatic compound $(=\mathrm{C}-\mathrm{H})$ bend at (909.5-697.0) $\mathrm{cm}^{-1}$ regions, which were characteristically similar to that of petroleum ether extract of $A$. occidentale. However, $n$-hexane extract of $P$. guajava exhibited cyanate C-N stretch at $1990.4 \mathrm{~cm}^{-1}$ as well as aromatic compound ring stretch at $1457.4 \mathrm{~cm}^{-1}$ (Table $4(C)$ ). It is worthwhile to note that $n$-hexane extract of $P$. guajava exhibited characteristically distinct primary and tertiary amines $(\mathrm{C}-\mathrm{N})$ stretch within the regions of (1155.51032.5) $\mathrm{cm}^{-1}$. 
Chloroform extract of $P$. guajava contained aliphatic compounds such as primary amines, alkanes, alkenes, and alkynes as well as aromatic compounds. Peaks within the regions of 3391.9-3615.5) $\mathrm{cm}^{-1}$ suggested primary $\mathrm{N}-\mathrm{H}$ stretch (Fig. 5d). Alkanes sp3 (-C-H) stretch, alkenes sp2 $(=\mathrm{C}-\mathrm{H})$ stretch, and alkynes sp $(\equiv \mathrm{C}-\mathrm{H})$ stretch, which were within the regions of $(3056.4-2307.2) \mathrm{cm}^{-1}$, were characteristic of chloroform extract of P. guajava (Table 4(D)). Peaks at $1733.2,1636.3$, and $1047.4 \mathrm{~cm}^{-1}$ were indicative of aldehyde $(\mathrm{HC}=\mathrm{O})$ stretch, amide $(\mathrm{N}-\mathrm{C}=\mathrm{O})$ stretch, and alkoxy C-O stretch (Table 4(D)).

Figure 5e showed that ethylacetate extract of $P$. guajava exhibited characteristic alcohol $(\mathrm{O}-\mathrm{H})$ stretch at region of $3444.1 \mathrm{~cm}^{-1}$ as well as band patterns that suggested the presence of aliphatic compounds $\{2981.9$ $\mathrm{cm}^{-1}$ (alkanes sp3 C-H stretch), $2091.0 \mathrm{~cm}^{-1}$ (alkynes sp $\mathrm{C}-\mathrm{H}$ stretch), $878.7 \mathrm{~cm}^{-1}$ (alkenes sp2 $\mathrm{C}-\mathrm{H}$ bend), 849.8 $\mathrm{cm}^{-1}$ (tri-substituted alkenes sp2 C-H bend), $785.5 \mathrm{~cm}^{-1}$ (cis-alkenes sp2 C-H bend), 738.0-83.018 $\mathrm{cm}^{-1}$ (cis-alkenes sp2 $\mathrm{C}-\mathrm{H}$ bend)\} (Table 4(E)). Ethylacetate extract of $P$. guajava showed evidence of the presence of carboxylic acids, aldehydes, phenolics, and esters, typified by peaks around $1889.8 \mathrm{~cm}^{-1}(\mathrm{C}=\mathrm{O})$ stretch, 1736.9 $\mathrm{cm}^{-1}(\mathrm{HC}=\mathrm{O})$ stretch, $1237.5 \mathrm{~cm}^{-1}$ acyl $(\mathrm{C}=\mathrm{O})$ stretch, and $1095.8 \mathrm{~cm}^{-1}$ alkoxy (C-O-R) stretch respectively. Table 4(E) showed that ethylacetate extract of $P$. guajava contained aromatic and nitro- compounds.

Ethylacetate extract of T. catappa exhibited characteristic alcohol $(\mathrm{O}-\mathrm{H})$ stretch around $3410.5 \mathrm{~cm}^{-1}$ (Fig. $5 \mathrm{f}$ ). Table 4(F) showed that ethylacetate extract of T. catappa contained aldehydes, aromatic and nitro- compounds, as well as phenolics and esters. Peaks around 2981.9 and $2907.0 \mathrm{~cm}^{-1}$ were evidence of the presence of aliphatic compounds in ethylacetate extract of $T$. catappa. Furthermore, medium band at $1043.7 \mathrm{~cm}^{-1}$, typified by $\mathrm{C}-\mathrm{O}$ stretch, was indicative of the presence of alkoxy group in ethylacetate extract of T. catappa. Peaks within the range of (939.3-849.8) $\mathrm{cm}^{-1}$ exhibited aliphatic sp2 $\mathrm{C}-\mathrm{H}$ bend, which was indicative of the presence of aliphatic compounds in ethylacetate extract of $T$. catappa.

\section{UV-visible spectra of fractionated leaf extracts}

Figure $6 \mathrm{a}-\mathrm{f}$ showed characteristic patterns of UV-visible spectra of selected fractionated leaf extracts of $A$. occidentale, $P$. guajava, and T. catappa. The multiple $\lambda \max$ of petroleum ether extract of $A$. occidentale was within the range of (224.00-272.00) $\mathrm{nm}$, which suggested the presence of nitrite (-ONO) and nitrate $\left(-\mathrm{NO}_{3}\right)$ chromophores in the extract (Fig. 6a). Figure 6b showed no evidence of presence of chromophores, within the UVvisible spectra, in ethylacetate extract of $A$. occidentale. The $n$-hexane extract of $P$. guajava gave $\lambda$ max within the range of (248.00-281.00) nm (Fig. 6c), whereas that of chloroform extract of P. guajava was between 200.00 and $281.00 \mathrm{~nm}$ (Fig. 6d). Ethylacetate extracts of $P$. guajava and T. catappa gave corresponding single $\lambda$ max at $217.00 \mathrm{~nm}$ (Fig. 6e) and $363.00 \mathrm{~nm}$ (Fig. 6f) respectively.

\section{Discussion}

The solid-liquid solvent extraction protocols are commonly used for the empirical evaluation of phytocomponents. The overall quality, phytochemical profile, and relative quantity (percentage yield) of plant extracts depend on a multitude of intrinsic elements such as age, species, and genetic constitution of the plant in addition to the plant parts of interest for empirical evaluation. The extrinsic factors include but not limited to growth conditions, geographical location, soil chemistry and seasonal period of the harvest of the plant materials (Mburu et al. 2012; Chikezie and Ojiako 2013; Mousavi et al. 2018). For the most part, the polarity of the solvent used in solid-liquid solvent extraction protocol has a bearing on the percentage yield of plant extracts (Mohd et al. 2012) composed of combinations of phytocomponents with diverse physical and chemical properties (Saxena et al. 2013). Furthermore, the phytochemical profile of fractionated extracts is intricately connected with the polarities of solvents of the partitioning cocktails as previously reported (Chikezie et al. 2015; Mousavi et al. 2018). Accordingly, fair insights into the physicochemical properties of the phytocomponents in a given plant material provide a guide for selecting the appropriate solvent for extraction protocol in order to achieve the maximum yield of their diverse phytocomponents. The present study showed variability in percentage yields of the fractionated leaf extracts of $A$. occidentale, $P$. guajava, and T. catappa, which contained combinations of phytocomponents of diverse biologic and chemical properties. The comparatively high yields of residual aqueous fractions of the plant materials suggested the presence of relatively high levels of hydrophilic phytocomponents in $A$. occidentale, $P$. guajava, and T. catappa leaf extracts. It is worthwhile to mention that hydrophilic and hydrophobic phytocomponents exhibit diverse biological activities, in which their ultimate pharmacological actions elicit therapeutic benefits or toxic outcomes (Chikezie et al. 2015).

$\mathrm{HbS}$ aggregation and polymerization are pivotal primary events leading to the distortion of sickle erythrocyte morphology and presentation of pathophysiologic indicators of SCD (Vekilov 2007; Uzunova et al. 2010; Piccin et al. 2019). In search of remedies for SCD, using in vitro models, previous empirical studies have demonstrated the capability of varieties of herbal extracts to control and impede $\mathrm{HbS}$ aggregation and polymerization (Okpuzor et al. 2008; Uwakwe and Nwaoguikpe 2008; Chikezie et al. 2010; Chikezie 2011; Imaga 2013; Dash 


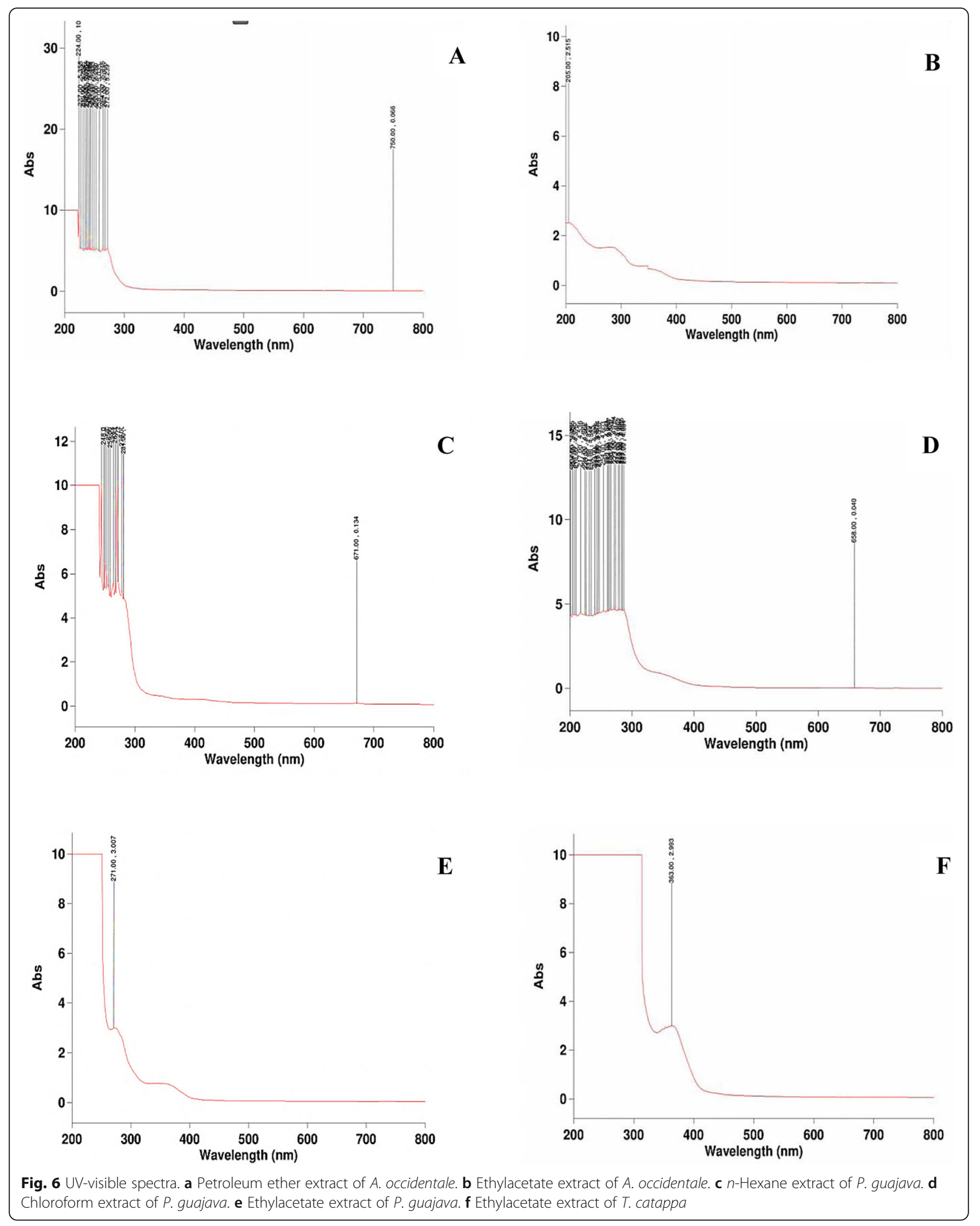


et al. 2013; Pauline et al. 2013; Nurain et al. 2017). In concord with previous reports, the outcome of the present investigations showed that certain fractionated leaf extracts of $A$. occidentale, $P$. guajava, and $T$. catappa attenuated the tendency of $\mathrm{HbS}$ to aggregate and polymerize in vitro. Selected fractionated leaf extracts, namely petroleum ether and ethylacetate extracts of $A$. occidentale, $n$-hexane, chloroform, and ethylacetate extracts of $P$. guajava, as well as ethylacetate extract of $T$. catappa, contained phytocomponents that attenuated intermolecular aggregation of $\mathrm{dHbS}-\mathrm{M}$.

In the absence of impeding molecular species, from plant extract, against $\mathrm{HbS}$ aggregation and polymerization, several mechanisms have been ascribed to the tendencies of phytocomponents to attenuate $\mathrm{HbS}$ aggregation and polymerization (Chikezie 2011; Syed et al. 2019). Based on previous reports and reviews, the options available include one or combinations of the following mechanisms:

i. The propensity of molecular species from plant extract to reversibly interact and interphase with complementary contact regions constituted by Valbeta6 residue of the docking $\mathrm{dHbS}-\mathrm{M}$ and Leubeta88, Phe-beta85, and Asp-beta73 residues of adjacent $\mathrm{dHbS}-\mathrm{M}$, and thereby, alters and shields the hydrophobic microenvironment of the contact regions required for $\mathrm{HbS}$ aggregation and polymerization (Chang et al. 1983; Charache et al. 1995; Abdulmalik et al. 2005; Eaton and Bunn 2017; Syed et al. 2019).

ii. The molecular species from plant extract stabilize $\mathrm{HbS}$ molecule by reversible non-covalent interactions that thermodynamically favour R-state HbS (Manning and Acharya 1984; Kark et al. 1988; Oyewole et al. 2008; Safo and Kato 2014; Oder et al. 2016; Eaton and Bunn 2017).

iii. Chemical modification of $\mathrm{HbS}$ molecule by molecular species from plant extract results in $\mathrm{HbS}$ derivatives that are adverse to aggregation and polymerization (Manning and Acharya 1984; Xu et al. 1999; Oder et al. 2016).

The major components of results of the present study appeared to suggest that reversible non-covalent interaction between phytocomponents from fractionated leaf extracts of A. occidentale, P. guajava, and T. catappa and $\mathrm{HbS}$, for the most parts, was responsible for the capacities of the phytocomponents to attenuate $\mathrm{HbS}$ aggregation and polymerization. However, the non-covalent interaction may possibly wane as the experimental time progressed due to relatively transient nature of the interaction. Furthermore, two competing thermodynamic favorable interactions, namely $\mathrm{dHbS}-\mathrm{M} . . . \mathrm{dHbS}-\mathrm{M}$ and $\mathrm{dHbS}-\mathrm{M} . .$. phytocomponent interactions were responsible for the dual behaviors, in certain instances (Tables 3 and 4), of phytocomponents from fractionated leaf extracts of $A$. occidentale, $P$. guajava, and T. catappa to either exacerbate or attenuate $\mathrm{HbS}$ aggregation and polymerization. Precisely, increased entropy kept the interacting species apart, whereas favorable free energy of intermolecular non-covalent interaction, measured by entropy gained, permitted the molecules to associate (Vekilov 2007; Syed et al. 2019). The molecular features of the interacting species and entropy of the interacting environment either exacerbated or attenuated $\mathrm{HbS}$ aggregation and polymerization. Accordingly, non-covalent interactions involving $\mathrm{dHbS}-\mathrm{M}$ and phytocomponents may be disrupted and displaced by more thermodynamic favored interactions with the progression of time, whereby $\mathrm{dHbS}-\mathrm{M} . . . \mathrm{dHbS}-\mathrm{M}$ interactions were favored fostering exacerbated $\mathrm{HbS}$ aggregation and polymerization or otherwise. Conversely, dHbS-M...phytocomponents interactions may attenuate $\mathrm{HbS}$ aggregation and polymerization provided the molecular configuration of the microenvironment of the contact regions required for $\mathrm{HbS}$ aggregation and polymerization was such that negated dHbS-M...dHbS-M interactions but promoted $\mathrm{dHbS}-\mathrm{M}$...phytocomponent interactions (Syed et al. 2019).

Another approach to deter $\mathrm{HbS}$ aggregation and polymerization involves the use of chemical agents that stabilize relax state (R-state) hemoglobin. The R-state $\mathrm{HbS}$ conformation is such that the contact regions required for $\mathrm{HbS}$ aggregation and polymerization are shielded, and as a result, do not form fibrous HbS polymers that engender erythrocyte sickling and ensuing clinical crisis (Safo and Kato 2014; Oder et al. 2016; Eaton and Bunn, 2017). It is remarkable to note that the presence of isothiocyanates in ethylacetate extract of $A$. occidentale obviously contributed, in parts, to impeding $\mathrm{HbS}$ aggregation and polymerization, which was in agreement with previous reports (Park et al. 2003; Safo and Kato 2014). Earlier reports showed that the thiols and isothiocyanates formed a covalent adduct with hemoglobin molecules, and thereby, modified the protein to an allosteric state of enhanced oxygen affinity that is adverse to polymerization (Park et al. 2003; Safo and Kato 2014). Specifically, studies showed that aliphatic isothiocyanates bound covalently to $\beta^{93}$ cystine (Cys-beta93) disrupted the native $\mathrm{T}$-state salt-bridge interaction between $\beta^{94}$ aspartate (Asp-beta94) and $\beta^{146}$ histidine (His-beta146), and thereby, destabilized the lower oxygen affinity $\mathrm{T}$-state of $\mathrm{HbS}$ that promoted hemoglobin aggregation and polymerization (Safo and Kato 2014; Oder et al. 2016). R-state HbS does not polymerize, whereas $\mathrm{T}$-state $\mathrm{HbS}$ forms fibrous polymer (Eaton and Hofrichter 1987).

Additionally, the previous report showed that isoquercitrin (quercetin-3-O- $\beta$-D-glucopyranoside) was one of the bioactive components from numerous medicinal 
plants that readily interacted with $\mathrm{HbS}$ and, as a result, impeded $\mathrm{HbS}$ aggregation and polymerization (Syed et al. 2019). Using circular dichroism (CD) spectroscopy, Syed et al. (2019) revealed that HbS...isoquercitrin complex exhibited helical structural changes leading to destabilization of HbS polymer as previously described (Hamdani et al. 2009; Ding et al. 2012; Pauline et al. 2013) as well as stabilized R-state of HbS. Their findings were in agreement with the proposed mode of action of phytocomponents investigated in the present study. Accordingly, isothiocyanates from ethylacetate extract of $A$. occidentale were stabilizers of $\mathrm{R}$-state of $\mathrm{HbS}$ in vitro as previously established (Park et al. 2003; Safo and Kato 2014).

Paradoxically, another selected fractionated leaf extracts of $A$. occidentale, $P$. guajava, and T. catappa were indicated to exacerbate $\mathrm{HbS}$ aggregation and polymerization (Tables 2 and 3), which was in concord with earlier reports (Chikezie et al. 2013). The present results suggest that these groups of fractionated leaf extracts of A. occidentale, P. guajava, and T. catappa, by virtue of their peculiar phytochemical profile, promoted $\mathrm{HbS}$ aggregation and polymerization. In a connected research outcome, Uzunova et al. (2010) had previously reported that the addition of $100-260 \mathrm{mM}$ of free heme to dialyzed $\mathrm{HbS}$ solutions exacerbated $\mathrm{HbS}$ aggregation and polymerization by two orders of magnitude than before dialysis. They noted that the removal of free heme from $\mathrm{HbS}$ solutions by dialysis lowered $\mathrm{HbS}$ polymerization activity and further proposed that the prevention of free heme accumulation in the erythrocyte cytosol was a therapeutic strategy against SCD.

Chemical modification of $\mathrm{HbS}$ molecule by phytocomponents from plant extracts was probably the basis for the rapid and sustained exponential reversion of $\mathrm{HbS}$ aggregation and polymerization, typified by $\mathrm{HbS}$ polymerization in the presence of residual aqueous of $A$. occidentale (Fig. 1e). It implied, therefore, that the physicochemical properties of phytocomponents from the fractionated leaf extracts of $A$. occidentale, $P$. guajava, and $T$. catappa had direct bearing on their capacities to alter the process leading to $\mathrm{HbS}$ aggregation and polymerization. Since intra-erythrocytic HbS aggregation and polymerization are pivotal to the pathogenesis and pathophysiology of SCD (Uzunova et al. 2010; Piccin et al. 2019), the use of chemical agents that covalently modify HbS molecules has been suggested to be an important approach to impede $\mathrm{dHbS}-\mathrm{M}$ aggregation and polymerization (Park et al. 2003; Eaton and Bunn 2017; Kassa et al. 2019). Covalent modification of HbS molecules by carbamylation using isothiocyanates, acetylation using methyl acetyl phosphate (MAP), and Snitrosylation of Cys-beta93 has been reported (Xu et al. 1999; Park et al. 2003; Chikezie, 2011; Jana et al. 2018). Furthermore, 5-hydroxymethyl-2-furfural (5HMF) forms a high-affinity Schiff-base adduct with $\mathrm{HbS}$ molecules, and thereby impede the tendency of $\mathrm{dHbS}-\mathrm{M}$ to aggregate and polymerize (Abdulmalik et al. 2005; Safo and Kato, 2014; Oder et al. 2016; Eaton and Bunn, 2017).

However, synthetic covalent modifiers that interrupted $\mathrm{HbS}$ aggregation and polymerization might cause undesirable chemical modifications of $\mathrm{HbS}$ molecules and other body protein molecules due to their non-specific chemical reactions (Safo and Kato 2014; Eaton and Bunn 2017). Although there are envisaged challenges in applying these options in the management of SCD as a result of a lack of stereo-specificity in dHbS-M...phytocomponents interactions at the complementary contact regions or allosteric sites of $\mathrm{dHbS}-\mathrm{M}$, this approach still offers rewarding prospects for alleviation of the sickling phenomena and therefore should not be discounted (Eaton and Bunn 2017).

The present study gave molecular insights into the identities of phytocomponents from fractionated leaf extracts of $A$. occidentale, $P$. guajava, and $T$. catappa that attenuated $\mathrm{HbS}$ aggregation and polymerization within the experimental time of $180 \mathrm{~s}$. The molecular features of the phytocomponents implicated in this regard, revealed by GC-MS and FT-IR systems analyses, were the aliphatic hydrocarbons, methylated esters, methylated long-chain and short-chain fatty acids, volatile alkanes, short-chain aliphatic alcohols, aromatic derivatives, cycloalkanes, phthalates, isothiocyanates, aminated sugars, cyclo-alcohols, and arachidyl alcohols (Tables 4(A-F) and Table 5(A-F)). Furthermore, UVvisible investigations revealed the presence of nitrocompounds in petroleum ether extract of $A$. occidentale as a phytocomponent that attenuated $\mathrm{HbS}$ aggregation and polymerization (Fig. 6v).

The present study showed that $n$-hexane extract of $P$. guajava exhibited the highest capacity to attenuate $\mathrm{HbS}$ aggregation and polymerization compared to other fractionated extracts of A. occidentale, P. guajava, and T. catappa. A combined result of GC-MS and FT-IR protocols showed that the phytocomponents from $P$. guajava that attenuated $\mathrm{HbS}$ aggregation and polymerization were viz. D-erythro-sphinganine, nitro compounds, tertiary amine, primary amine, di-, tri-substituted aromatic compounds, cyanate, and esters.

The present study further confirmed the usefulness of GC-MS systems in identification, quantification, and characterization of a mixture of phytocomponents with commensurate reproducibility and reliable outcomes. Accordingly, the application of GC-MS systems protocols, which unravel the nature, quantity, and chemical structures as well as molecular fingerprints of the vast array of phytocomponents from biologic systems have been widely reported (Sasidharan et al. 2011; Sampaio et al. 2011; Rašković et al. 2015; Cyril-Olutayo et al. 2019). To mention but a few, the findings of the present 
Table 5 FT-IR spectra peak values of (A) petroleum ether extract of A. occidentale, (B) ethylacetate extract of A. occidentale, (C) $n$ hexane extract of P. guajava, (D) chloroform extract of P. guajava, (E) ethylacetate extract of P. guajava, and (F) ethylacetate extract of T. catappa

\begin{tabular}{|c|c|c|c|c|}
\hline $\mathrm{S} / \mathrm{No}$ & Peak/band $\left(\mathrm{cm}^{-1}\right)$ & \%Т & Functional groups/assignment & Origin \\
\hline \multicolumn{5}{|l|}{$\bar{A}$} \\
\hline 1. & 2955.8 & 67.950 & Alkanes sp3 C-H stretch & $\mathrm{C}-\mathrm{H}$ \\
\hline 2. & 2926.0 & 62.776 & Alkanes sp3 C-H stretch & $\mathrm{C}-\mathrm{H}$ \\
\hline 3. & 2855.1 & 78.007 & Aldehyde $\mathrm{C}-\mathrm{H}$ stretch & $\mathrm{C}-\mathrm{H}$ \\
\hline 4. & 1748.1 & 98.517 & Ester carbonyl C-O stretch & $\mathrm{C}=\mathrm{O}$ \\
\hline 5. & 1606.5 & 99.085 & Conjugated alkenes C-C & $C=C$ \\
\hline 6. & 1453.7 & 82.438 & Aromatic compounds $C-C$ stretch & $C=C$ \\
\hline 7. & 1379.4 & 91.002 & Acyl C-O; phenol C-O stretch & $\mathrm{C}=\mathrm{O} ; \mathrm{C}-\mathrm{O}$ \\
\hline 8. & 1237.5 & 97.513 & Aromatic ethers, aryl-O stretch & Ar-O-C \\
\hline 9. & 1036.2 & 97.765 & Alkoxy C-O stretch & $\mathrm{X}-\mathrm{O}-\mathrm{C}$ \\
\hline 10. & 905.7 & 97.513 & Mono-substituted alkene sp2 C-H bend & $=\mathrm{C}-\mathrm{H}$ \\
\hline 11. & 767.8 & 97.464 & Di-substituted aromatic sp2 $\mathrm{C}-\mathrm{H}$ bend & $=\mathrm{C}-\mathrm{H}$ \\
\hline 12. & 726.8 & 87.966 & Mono-substituted aromatic sp2 $\mathrm{C}-\mathrm{H}$ bend & $=\mathrm{C}-\mathrm{H}$ \\
\hline 13. & 693.3 & 94.726 & Di-substituted aromatic sp2 C-H bend & $=\mathrm{C}-\mathrm{H}$ \\
\hline \multicolumn{5}{|l|}{ B } \\
\hline 1. & 3444.1 & 87.566 & Dimeric O-H stretch & $\mathrm{O}-\mathrm{H}$ \\
\hline 2. & 2989.1 & 87.083 & Alkanes sp3 C-H stretch & $\mathrm{C}-\mathrm{H}$ \\
\hline 3. & 2907.3 & 95.394 & Alkanes sp3 C-H stretch & $\mathrm{C}-\mathrm{H}$ \\
\hline 4. & 2091.0 & 98.362 & Isothiocyanate (-SCN) stretch & $-\mathrm{SCN}$ \\
\hline 5. & 1889.8 & 98.918 & Carboxylic acids C-O stretch & $\mathrm{C}=\mathrm{O}$ \\
\hline 6. & 1736.9 & 45.205 & Ester C-O stretch & $\mathrm{C}=\mathrm{O}$ \\
\hline 7. & 1654.9 & 88.777 & Amides C-O stretch & $\mathrm{C}=\mathrm{O}$ \\
\hline 8. & 1446.2 & 86.722 & Aromatic compounds C-C stretch & $C=C$ \\
\hline 9. & 1376.9 & 45.205 & Acyl C-O; phenol C-O stretch & $\mathrm{C}=\mathrm{O} ; \mathrm{C}-\mathrm{O}$ \\
\hline 10. & 1237.5 & 26.947 & Skeletal C-C vibration & $C-C$ \\
\hline 11. & 1092.1 & 80.365 & Alkoxy C-O stretch & $\mathrm{X}-\mathrm{O}-\mathrm{C}$ \\
\hline 12. & 1043.7 & 32.142 & Primary amine C-N stretch & $\mathrm{C}-\mathrm{N}$ \\
\hline 13. & 939.3 & 87.721 & Alkenes sp2 C-H bend & $=\mathrm{C}-\mathrm{H}$ \\
\hline 14. & 878.7 & 87.409 & Alkenes sp2 $\mathrm{C}-\mathrm{H}$ bend & $=\mathrm{C}-\mathrm{H}$ \\
\hline 15. & 849.8 & 83.588 & Tri-substituted alkenes sp2 C-H bend & $\mathrm{C}-\mathrm{H}$ \\
\hline 16. & 786.5 & 85.048 & Di-substituted aromatic sp C-H bend & $\mathrm{C}-\mathrm{H}$ \\
\hline 17. & 733.0 & 83.080 & Mono-substituted aromatic $\mathrm{C}-\mathrm{H}$ bend & $\mathrm{C}-\mathrm{H}$ \\
\hline \multicolumn{5}{|l|}{$\mathrm{C}$} \\
\hline 1. & 2955.8 & 83.080 & Alkanes sp3 C-H stretch & $\mathrm{C}-\mathrm{H}$ \\
\hline 2. & 2926.0 & 60.632 & Alkanes sp3 C-H stretch & $\mathrm{C}-\mathrm{H}$ \\
\hline 3. & 2858.9 & 89.315 & Alkanes sp3 C-H stretch & $\mathrm{C}-\mathrm{H}$ \\
\hline 4. & 2728.4 & 99.307 & Aldehyde C-H stretch & $\mathrm{C}-\mathrm{H}$ \\
\hline 5. & 1990.4 & 99.392 & Cyanate C-N stretch & $-C \equiv N$ \\
\hline 6. & 1748.1 & 99.203 & Esters C-O stretch & $\mathrm{C}=\mathrm{O}$ \\
\hline 7. & 1610.2 & 98.594 & Conjugated alkenes $\mathrm{C}-\mathrm{C}$ stretch & $C=C$ \\
\hline 8. & 1457.4 & 91.799 & Aromatic ring stretch & $C=C$ \\
\hline 9. & 1379.1 & 96.026 & Nitro compounds $\mathrm{NO}_{2}$ stretch & $-\mathrm{N}=\mathrm{O}$ \\
\hline
\end{tabular}


Table 5 FT-IR spectra peak values of (A) petroleum ether extract of A. occidentale, (B) ethylacetate extract of A. occidentale, (C) $n$ hexane extract of $P$. guajava, (D) chloroform extract of $P$. guajava, (E) ethylacetate extract of $P$. guajava, and (F) ethylacetate extract of T. catappa (Continued)

\begin{tabular}{|c|c|c|c|c|}
\hline $\mathrm{S} / \mathrm{No}$ & Peak/band $\left(\mathrm{cm}^{-1}\right)$ & \%Т & Functional groups/assignment & Origin \\
\hline 10. & 1155.5 & 98.738 & Tertiary amine C-N stretch & C-N \\
\hline 11. & 1032.5 & 98.385 & Primary amine C-N stretch & C-N \\
\hline 12. & 909.5 & 98.686 & Vinyl C-H bend & $\mathrm{C}-\mathrm{H}$ \\
\hline 13. & 805.1 & 98.057 & Di-substituted aromatic $\mathrm{C}-\mathrm{H}$ bend & $\mathrm{C}-\mathrm{H}$ \\
\hline 14. & 767.8 & 97.557 & Di-substituted aromatic $\mathrm{C}-\mathrm{H}$ bend & $\mathrm{C}-\mathrm{H}$ \\
\hline 15. & 730.6 & 95.929 & Cis-alkenes sp2 C-H bend & $\mathrm{C}-\mathrm{H}$ \\
\hline 16. & 697.0 & 96.671 & Cis-alkenes sp2 C-H bend & $\mathrm{C}-\mathrm{H}$ \\
\hline \multicolumn{5}{|l|}{ D } \\
\hline 1. & 3615.5 & 97.573 & Primary amines $\mathrm{N}-\mathrm{H}$ stretch & $\mathrm{N}-\mathrm{H}$ \\
\hline 2. & 3391.9 & 94.951 & Primary amines N-H stretch & $\mathrm{N}-\mathrm{H}$ \\
\hline 3. & 3056.4 & 96.541 & Aromatic compound C-H stretch & $\mathrm{C}-\mathrm{H}$ \\
\hline 4. & 2974.4 & 92.265 & Alkanes sp3 C-H stretch & $\mathrm{C}-\mathrm{H}$ \\
\hline 5. & 2892.4 & 96.394 & Alkanes sp3 C-H stretch & $\mathrm{C}-\mathrm{H}$ \\
\hline 6. & 2307.2 & 99.009 & Alkynes sp C-C stretch & $C \equiv C$ \\
\hline 7. & 1733.2 & 95.893 & Aldehyde C-O stretch & $\mathrm{C}=\mathrm{O}$ \\
\hline 8. & 1636.3 & 98.056 & Amides C-O stretch & $\mathrm{C}=\mathrm{O}$ \\
\hline 9. & 1423.8 & 94.187 & Alkanes sp3 C-H bend & $\mathrm{C}-\mathrm{H}$ \\
\hline 10. & 1267.3 & 60.465 & Alkyl \& aryl halides (C-F stretch) & $C-F$ \\
\hline 11. & 1047.4 & 75.523 & Alkoxy C-O stretch & $\mathrm{X}-\mathrm{O}-\mathrm{C}$ \\
\hline 12. & 879.7 & 89.739 & Alkenes sp2 C-H bend & $=\mathrm{C}-\mathrm{H}$ \\
\hline 13. & 730.6 & 12.893 & Para-aromatic sp2 C-H bend & $\mathrm{C}-\mathrm{H}$ \\
\hline \multicolumn{5}{|l|}{$E$} \\
\hline 1. & 3444.1 & 89.445 & Alcohols O-H stretch & $\mathrm{O}-\mathrm{H}$ \\
\hline 2. & 2981.9 & 87.541 & Alkanes sp3 C-H stretch & $\mathrm{C}-\mathrm{H}$ \\
\hline 3. & 2907.3 & 95.268 & Aldehydes C-H stretch & $\mathrm{C}-\mathrm{H}$ \\
\hline 4. & 2091.0 & 98.579 & Alkynes sp C-C stretch & $C \equiv C$ \\
\hline 5. & 1889.8 & 98.809 & Carboxylic acid C-O stretch & $\mathrm{C}=\mathrm{O}$ \\
\hline 6. & 1736.9 & 44.150 & Aldehyde C-O stretch & $\mathrm{C}=\mathrm{O}$ \\
\hline 7. & 1446.2 & 87.344 & Aromatic compounds C-C stretch & $C=C$ \\
\hline 8. & 1375.4 & 60.518 & Nitro compounds $\mathrm{NO}_{2}$ stretch & $-\mathrm{N}=\mathrm{O}$ \\
\hline 9. & 1237.5 & 27.455 & Aromatic phosphates P-O-C stretch & $\mathrm{P}-\mathrm{O}-\mathrm{C}$ \\
\hline 10. & 1095.8 & 82.220 & Alkoxy C-O stretch & $\mathrm{X}-\mathrm{O}-\mathrm{C}$ \\
\hline 11. & 1043.7 & 33.483 & Primary amine $\mathrm{C}-\mathrm{N}$ stretch & $\mathrm{C}-\mathrm{N}$ \\
\hline 12. & 878.7 & 89.082 & Aromatic phosphates P-O-C stretch & $\mathrm{P}-\mathrm{O}-\mathrm{C}$ \\
\hline 13. & 849.8 & 83.047 & Tri-substituted alkenes sp2 C-H bend & $\mathrm{C}-\mathrm{H}$ \\
\hline 14. & 785.5 & 86.047 & Cis-alkenes sp2 C-H bend & $\mathrm{C}-\mathrm{H}$ \\
\hline 15. & 738.0 & 74.085 & Cis-alkenes sp2 C-H bend & $\mathrm{C}-\mathrm{H}$ \\
\hline 16. & 704.5 & 83.018 & Cis-alkenes sp2 C-H bend & $\mathrm{C}-\mathrm{H}$ \\
\hline \multicolumn{5}{|l|}{$\mathrm{F}$} \\
\hline 1. & 3410.5 & 77.486 & Alcohols O-H stretch & $\mathrm{O}-\mathrm{H}$ \\
\hline 2. & 2981.9 & 85.453 & Alkanes sp3 C-H stretch & $\mathrm{C}-\mathrm{H}$ \\
\hline 3. & 2907.3 & 93.016 & Alkanes sp3 C-H stretch & $\mathrm{C}-\mathrm{H}$ \\
\hline
\end{tabular}


Table 5 FT-IR spectra peak values of (A) petroleum ether extract of A. occidentale, (B) ethylacetate extract of A. occidentale, (C) $n$ hexane extract of $P$. guajava, (D) chloroform extract of $P$. guajava, (E) ethylacetate extract of $P$. guajava, and (F) ethylacetate extract of T. catappa (Continued)

\begin{tabular}{|c|c|c|c|c|}
\hline S/No & Peak/band $\left(\mathrm{cm}^{-1}\right)$ & $\% \mathrm{~T}$ & Functional groups/assignment & Origin \\
\hline 4. & 1725.8 & 56.071 & Aldehyde C-O stretch & $\mathrm{C}=\mathrm{O}$ \\
\hline 5. & 1446.2 & 86.294 & Aromatic compounds $C-C$ stretch & $C=C$ \\
\hline 6. & 1375.4 & 62.498 & Nitro compounds $\mathrm{NO}_{2}$ stretch & $-\mathrm{N}=\mathrm{O}$ \\
\hline 7. & 1241.2 & 40.429 & Acyl C-O; phenol C-O stretch & $\mathrm{C}-\mathrm{O}$ \\
\hline 8. & 1088.4 & 77.450 & Alkoxy C-O stretch & $\mathrm{X}-\mathrm{O}-\mathrm{C}$ \\
\hline 9. & 1043.7 & 35.790 & Alkoxy C-O stretch & $\mathrm{X}-\mathrm{O}-\mathrm{C}$ \\
\hline 10. & 939.3 & 88.215 & Mono-alkenes sp2 C-H bend & $\mathrm{C}-\mathrm{H}$ \\
\hline 11. & 879.7 & 79.321 & Alkene sp2 C-H bend & $\mathrm{C}-\mathrm{H}$ \\
\hline 12. & 849.8 & 81.398 & Tri-substituted alkenes sp2 C-H bend & $\mathrm{C}-\mathrm{H}$ \\
\hline
\end{tabular}

$\% T$ percentage transmittance

study, using bioassay-guided approach in vitro in conjunction with the GC-MS and FT-IR systems analyses, suggested that methylated esters such as methyl tetradecanoate, hexadecanoic acid, methyl ester, pentadecanoic acid, 14-methyl-methyl ester, 9, 12-octadecadienoic acid, (Z, Z)-methyl ester, 11-octadecenoic acid, methyl ester, and 9-octadecenoic acid, methyl ester (E)- were phytocomponents from petroleum ether extract of A. occidentale that attenuated $\mathrm{HbS}$ aggregation and polymerization. The phytocomponents from fractionated leaf extracts of A. occidentale, P. guajava, and T. catappa that attenuated $\mathrm{HbS}$ aggregation and polymerization are summarized (Table 4).

There are reports on other biological activities and medicinal properties of these methylated esters. For instance, methyl tetradecanoate is a platelet aggregation inhibitor used for the prevention and treatment of cerebral injuries of hemorrhagic or ischemic origin (Nagarjunakonda et al. 2017). In addition to the potentials of hexadecanoic acid, methyl ester to attenuate $\mathrm{HbS}$ aggregation and polymerization, as our present findings suggest, previous studies showed that hexadecanoic acid, methyl ester from calyx of Hibiscus sabdariffa (green roselle) elicited membrane autolysis, inhibited biosynthesis of nitric oxide, phagocytic activity of certain cells, as well as lowered tumor necrosis factor-alpha (TNF $\alpha$ ), interleukin-10 (IL-10), and prostaglandin E2 (PGE2) activities and induced dilation of the aorta (Cai et al. 2005; Sarkar et al. 2006; Lin et al. 2009). Methyl stearate is an anti-helminthic, anti-fungal, and anti-nociceptive agent as well as a potent $\gamma$-amino butyric acid (GABA) aminotransferase inhibitor, lipid metabolism regulator, gastrin inhibitor, and exhibits antioxidant activity (Pinto et al. 2017; Adnan et al. 2019). Other notable biological activities and medicinal properties of few other phytocomponents, as our present findings suggest, that attenuated $\mathrm{HbS}$ aggregation and polymerization are summarized elsewhere: viz. pentadecanoic acid, 14-methyl-, methyl ester (antioxidant) (Vijisaral and Arumugam 2014), phthalates (antibacterial) (Khatiwora et al. 2012), isothiocyanates (antimicrobial) (Dias et al. 2014), and arachidyl alcohols (Garaniya and Bapodra 2014).

\section{Conclusion}

The fractionated leaf extracts of A. occidentale, P. guajava, and T. catappa that exhibited comparatively high potency to attenuate $\mathrm{HbS}$ aggregation and polymerization were as follows: petroleum ether extract of $A$. occidentale, ethylacetate extract of $A$. occidentale, as well as $n$-hexane extract of $P$. guajava. Other fractionated leaf extracts that attenuated $\mathrm{HbS}$ aggregation and polymerization were chloroform extract of $P$. guajava, ethylacetate extract of $P$. guajava, and ethylacetate extract of T. catappa. The fractionated leaf extracts of $A$. occidentale, $P$. guajava, and T. catappa exhibited differential capacities to impede $\mathrm{HbS}$ aggregation and polymerization in the order of $n$-hexane extract of $P$. guajava > ethylacetate extract of $A$. occidentale > ethylacetate extract of $P$. guajava > ethylacetate extract of $T$. catappa $>$ petroleum ether extract of $A$. occidentale.

The identification, quantitation, and characterization methods using GC-MS in conjunction with FT-IR and UV-visible systems protocols revealed combinations of 53 phytocomponents from the fractionated leaf extracts of A. occidentale, P. guajava, and T. catappa as molecular species that impeded $\mathrm{HbS}$ aggregation and polymerization in vitro. In general terms, the phytocomponents from the fractionated leaf extracts that attenuated $\mathrm{HbS}$ aggregation and polymerization include the aliphatic hydrocarbons, methylated esters, methylated long-chain and short-chain fatty acids, volatile alkanes, short-chain aliphatic alcohols, D-erythro-sphinganine, aromatic derivatives, cycloalkanes, phthalates, isothiocyanates, aminated sugars, cyclo-alcohols, arachidyl alcohols, and nitro-compounds. 
The effectiveness of GC-MS, FT-IR, and UV-visible systems protocols notwithstanding, identification of unknown molecular species largely relied on comparison with known molecules from a database/library and established chromatogram and fingerprints patterns. Consequently, the use of these methods for the classification of phytocomponents into functional and structural groups comes with few drawbacks and challenges. Therefore, it is recommended that further investigations should be carried out for such exercise. Additionally, in order to confirm the specific identities of the phytocomponents that attenuated $\mathrm{HbS}$ aggregation and polymerization, it is recommended that another study on isolation and purification of the phytocomponents, suggested in the present study, should be applied in further $\mathrm{HbS}$ polymerization studies in vitro as well as the use transgenic sickle animal model.

\section{Abbreviations}

GC-MS: Gas chromatography-mass spectrometry; FT-IR: Fourier transforminfrared spectrometry; UV-visible: Ultraviolet-visible spectroscopy; Poly-dHbSM: Polymerization of deoxygenated sickle hemoglobin molecules; PBS: Phosphate-buffered saline; $\mathrm{NaCl}$ : Sodium chloride; $\mathrm{Na}_{2} \mathrm{~S}_{2} \mathrm{O}_{5}$ : Sodium metabisulfite; RCPI\%: Relative cumulative polymerization index; HbS: Sickle hemoglobin; HbSS: Homozygous sickle hemoglobin; dHbS-M: Deoxygenated sickle hemoglobin molecules; SCD: Sickle cell disease; HbF: Fetal hemoglobin; $\mathrm{Na}_{2} \mathrm{HPO}_{4} \cdot 2 \mathrm{H}_{2} \mathrm{O}$ : Disodium hydrogen phosphate dihydrate; $\mathrm{NaH}_{2} \mathrm{PO}_{4} \cdot 2 \mathrm{H}_{2} \mathrm{O}$ : Sodium dihydrogen phosphate dihydrate

\section{Acknowledgements}

The authors are grateful for the technical assistance offered by Mr. F.C. Emengaha, Chief Academic Technologist, Department of Medical Biochemistry, College of Medicine and Mr. C.O. Kabiri, Senior Laboratory Technologist, Department of Biochemistry, Faculty of Science, Imo State University, Owerri. Mr. Franklyn O. Ohiagu efforts are highly appreciated.

\section{Authors' contributions}

PCC conceived and designed the research and supervised the laboratory work. PCC prepared the manuscript. PCC/RCE/ABC-A analyzed the data. PCC/ RCE/ABC-A collected the plant samples and carried out the laboratory work. PCC supervised the laboratory work. All authors have approved the manuscript in the present form and gave the permission to submit the manuscript for publication.

\section{Funding}

This work was supported by Imo State University, Owerri, and research grant offered by the Tertiary Education Trust Fund (TETFund) Research Based Interventions of Nigerian Universities. Imo State University, Owerri, provided the laboratory space and infrastructures. TETFund provided the financial resources for purchase of laboratory chemicals/reagents and instruments as well as expenses pertaining to transportation and travels. Grant Number: TETFUND/DRSS/UNIV/OWERRI/2015/5RP VOL 1 (7).

\section{Availability of data and materials}

All the data generated and analyzed during the study are included in the main manuscript.

\section{Ethics approval and consent to participate}

The collection of the blood samples was in accordance with the ethical principles that have their origins in the October 2008 Declaration of Helsinki. The present study was approved by the Ethical Committee for Research, Department of Biochemistry, Imo State University, Owerri, Nigeria. Ethics Approval Number: ODVC/REN/544/19. Written consent was obtained whereby all the participants filled and signed an Informed Consent Form.
Consent for publication

Not applicable.

\section{Competing interests}

The authors declare that they have no competing interests.

Received: 14 July 2020 Accepted: 6 August 2020

Published online: 17 August 2020

\section{References}

Abdulmalik O, Safo MK, Chen Q, Yang J, Brugnara C, Ohene-Frempong K (2005) 5-hydroxymethyl-2-furfural modifies intracellular sickle haemoglobin and inhibits sickling red blood cells. Br J Haematol 128:552-561

Adachi KS, Konitzer P, Paulraj CG, Surre S (1994) Role of Leu- $\beta 88$ in the hydrophobic acceptor pocket for Val- $\beta 6$ during hemoglobin $\mathrm{S}$ polymerization. J Biol Chem 269(26):17477-17480

Adewoyin AS, Alagbe AE, Adedokun BO, Idubor NT (2015) Knowledge, attitude and control practices of sickle cell disease among youth corps members in Benin City, Nigeria. Ann Ibadan Postgrad Med 13(2):100-107

Adnan M, Chy NU, Kamal ATM, Azad MOK, Paul A, et al. (2019) Investigation of the biological activities and characterization of bioactive constituents of Ophiorrhiza rugosa var. prostrata (D.Don) and Mondal leaves through in vivo, in vitro, and in silico approaches. Mole 24:1367. 24 pages.

Bain B, Bates I, Laffan M (2012) Dacie and Lewis practical haematology. Amsterdam. The Netherlands, Elsevier Health Sciences

Bianchi N, Zuccato C, Lampronti I, Borgatti M, Gambari R (2009) Fetal hemoglobin inducers from the natural world: a novel approach for identification of drugs for the treatment of $\beta$-thalassemia and sickle-cell anemia. Compl Altern Med 6(2):141-151

Cai P, Kaphalia BS, Ansari GA (2005) Methyl palmitate: inhibitor of phagocytosis in primary rat Kupffer cells. Toxicol 210:197-204

Chang H, Ewert SM, Nagel RL (1983) Identification of 2-imidazolines as antisickling agents. Am Soc Pharmacol Exp Ther 23(3):731-734

Charache S, Terrin M, Moore R, Dover G, Barton F, Eckert S (1995) The effect of hydroxyurea on the frequency of painful crises in sickle cell anemia. N Engl J Med 332:1317-1322

Chikezie PC (2011) Sodium metabisulphite induced polymerization of sickle cell haemoglobin $(\mathrm{HbS})$ incubated in extracts of three medicinal plants (Anacardium occidentale, Psidium guajava and Terminalia catappa). Pharmacogn Mag 7(26):126-132

Chikezie PC, Akuwudike AR, Chikezie CM (2013) Polymerization studies of sickle cell hemoglobin incubated in aqueous leaf extract of Nicotiana tabacum product. Res J Med Plant 7(2):92-99

Chikezie PC, Chikezie CM, Amaragbulem PI (2010) Effect of antimalarial drugs on polymerization of sickle cell hemoglobin (HbS). Turk J Biochem 35(1):41-44

Chikezie PC, Ibegbulem CO, Mbagwu FN (2015) Bioactive principles from medicinal plants. Res J Phytochem 9(3):88-115

Chikezie PC, Ojiako AO (2013) Cyanide and aflatoxin loads of processed Cassava (Manihot esculenta) tubers (Garri) in Njaba, Imo State, Nigeria. Toxicol Int 20(3):261-267

Chikezie PC, Uwakwe AA (2011) Membrane stability of sickle erythrocytes incubated in extracts of three medicinal plants: Anacardium occidentale, Psidium guajava and Terminalia catappa. Pharmacogn Mag 7(26):121-125

Cokic VP, Smith RD, Beleslin-Cokic BB, Njoroge JM, Miller JL et al (2003) Hydroxyurea induces fetal hemoglobin by the nitric oxide-dependent activation of soluble guanylyl cyclase. J Clin Invest 111(2):231-239

Cyril-Olutayo MC, Agbedahunsi JM, Akinola NO (2019) Studies on the effect of a nutritious vegetable, Telfairia occidentalis, on HbSS blood. J Tradit Compl Med 9:156-162

Dash BP, Archana Y, Satapathy N, Naik SK (2013) Search for antisickling agents from plants. Pharmacogn Rev 7(13):53-60

Diallo D, Tchernia G (2002) Sickle cell disease in Africa. Curr Opin Hematol 9(2): $111-116$

Dias C, Aires A, Saavedra MJ (2014) Antimicrobial activity of isothiocyanates from cruciferous plants against methicillin-resistant Staphylococcus aureus (MRSA). Int J Mol Sci 15:19552-19561

Ding F, Liu W, Sun Y, Yang X-L, Sun Y et al (2012) Analysis of conjugation of chloramphenicol and hemoglobin by fluorescence, circular dichroism and molecular modeling. J Mol Struct 1007:81-87

Eaton WA, Bunn HF (2017) Treating sickle cell disease by targeting HbS polymerization. Blood 129(20):2719-2726 
Eaton WA, Hofrichter J (1987) Hemoglobin S gelation and sickle cell disease. Blood. 70:1245-1266

Eliot R, Davies M, Hamse DJ (2006) Dermatomyositis-like eruption with long-term hydrourea. Br J Dermatol 17:56-60

Ezekwe SA, Chikezie PC (2017) GC-MS analysis of aqueous extract of unripe fruit of Carica papaya. J Nutr Food Sci 7(3):5 pages.

Ferrone FA, Ivanova M, Jasuja R (2002) Heterogeneous nucleation and crowding in sickle hemoglobin: An analytic approach. Biophys J 82(1):399-406

Frenette PS, Atweh GF (2007) Sickle cell disease: Old discoveries, new concepts, and future promise. J Clin Invest 117:850-858

Garaniya N, Bapodra A (2014) Ethnobotanical and phytopharmacological potential of Abrus precatorius L:: A review. Asian Pac J Trop Biomed 4(1):S27-S34

Grosse SD, Odame I, Atrash HK, Amendah DD, Piel FB, Williams TN (2011) Sickle cell disease in Africa: A neglected cause of early childhood mortality. Am J Prev Med 41(6S4):S398-S405.

Hamdani S, Joly D, Carpentier R, Tajmir-Riahi HA (2009) The effect of methylamine on the solution structures of human and bovine serum albumins. J Mol Struct 936(1-3):80-86

Hemavathy A, Shanthi P, Sowndharya C, Thiripura SS, Priyadharshni K (2019) Extraction and isolation of bioactive compounds from a therapeutic medicinal plant - Wrightia tinctoria (Roxb.) R. Br Int J Pharmacogn Phytochem Res 11(3):199-204

Ighodaro OM, Akinloye OA, Ugbaja RN, Omotainse SO, Faokunla O (2016) FT-IR analysis of Sapium ellipticum (Hochst) pax ethanol leaf extract and its inhibitory effects on pancreatic a-amylase and intestinal a-glucosidase activities in vitro. Egypt J Basic Appl Sci 3(4):343-349

Imaga NA (2013) Phytomedicines and nutraceuticals: alternative therapeutics for sickle cell anemia. Sci World J 2013: Article ID 269659, 12 pages.

Jana S, Strader MB, Meng F, Hicks W, Kassa T et al (2018) Hemoglobin oxidationdependent reactions promote interactions with band 3 and oxidative changes in sickle cell-derived microparticles. JCI Insight 3(21):e120451

Kapoor S, Little JA, Pecker LH (2018) Advances in the treatment of sickle cell disease. Mayo Clin Proc 93(12):1810-1824

Karayil S, Chandran KPS, Sudeesh PS, Veraiah K (2014) Isolation and Structural elucidation of novel bioactive molecule-Coumarin from traditionally used medicinal plant-Ceropegia juncea (Roxb.). IOSR. J Pharm Biol Sci 9:19-22

Kark JA, Kale MP, Tarassoff PG, Woods M, Lessin LS (1988) Inhibition of erythrocyte sickling in vitro by pyridoxal. J Clin Invest 62:888-891

Kassa T, Wood F, Strader MB, Alayash Al (2019) Antisickling drugs targeting $B$ Cys93 reduces iron oxidation and oxidative changes in sickle cell hemoglobin. Front Physiol 10(931):1-12

Khatiwora E, Adsul VB, Kulkarni M, Deshpande NR, Kashalkar RV (2012) Antibacterial activity of Dibutyl phthalate: a secondary metabolite isolated from Ipomoea carnea stem. J Pharm Res 5(1):150-152

Lin HW, Liu CZ, Cao D, Chen PY, Chen MF et al (2009) Endogenous methyl palmitate modulates nicotinic receptor-mediated transmission in the superior cervical ganglion. Proc Nat Acad Sci, USA 105:19526-19531

Makani J, Ofori-Acquah SF, Nnodu O, Wonkam A, Ohene-Frempong K (2013) Sickle cell disease: new opportunities and challenges in Africa. Sci World J Article ID 193252:16 pages

Manning JM, Acharya AS (1984) The mechanism of action of two antisickling agents: Sodium cyanate and glyceraldehyde. Am J Pediatr Hematol Oncol 6: $51-54$

Martins DW (1983) Structure and function of a protein-haemoglobin. In: Harper's Review of Biochemistry. Martin DW, Mayes PA, Rodwell WW. (Editors). $9^{\text {th }}$ Edition. Lange Medical Publications. California. pp. 40-50.

Mburu FW, Swaleh S, Njue W (2012) Potential toxic levels of cyanide in cassava (Manihot esculenta Crantz) grown in Kenya. Afr J Food Sci 6:416-420

Mohd FB, Abdul R, Pin KY, Zamree MS, Luqman CA et al (2012) The effects of varying solvent polarity on extraction yield of Orthosiphon stamineus leaves. $J$ Appl Sci. 12:1207-1210

Mousavi B, Tafvizi F, Zaker BS (2018) Green synthesis of silver nanoparticles using Artemisia turcomanica leaf extract and the study of anti-cancer effect and apoptosis induction on gastric cancer cell line. Artif Cell Nanomed Biotechnol 46(1):499-510

Mulumba LL, Wilson L (2015) Sickle cell disease among children in Africa: An integrative literature review and global recommendations. Int J Afr Nursing Sci 3:56-64

Nagarjunakonda S, Amalakanti S, Dhishana SR, Ramaiah M, Rajanala L (2017) GCMS analysis of Indrakeeladri native medicine used in the treatment of stroke. Pharmacogn J 9(1):102-106
Nurain IO, Bewaji CO, Johnson JS, Davenport RD, Zhang Y (2017) Potential of three ethnomedicinal plants as antisickling agents. Mol Pharm 14(1):172-182

Oder E, Safo MK, Abdulmalik O, Kato GJ, Discovery D (2016) New developments in anti-sickling agents: Can drugs directly prevent the polymerization of sickle haemoglobin in vivo? Br J Haematol 175(1):24-30

Ojiako AO, Chikezie PC, Ogbuji CA (2015) Histopathological studies of renal and hepatic tissues of hyperglycemic rats administered traditional herbal formulations. Int J Green Pharm 9(3):184-191

Okoye TC, Akah PA, Okoli CO, Ezike AC, Mbaoji FN (2010) Antimicrobial and antispasmodic activity of leaf extract and fractions of Stachytarpheta cayennensis. Asian Pac J Trop Med 2010:189-192

Okpuzor J, Adebesin O, Ogbunugafor H, Amadi I (2008) The potential of medicinal plants in sickle cell disease control: A review. Int J Biomed Health Sci 4(2):47-55

Oyewole O, Malomo S, Adebayo J (2008) Comparative studies on antisickling properties of thiocyanate, tellurite and hydroxyurea. Pak J Med Sci 24(1):18

Park S, Hayes BL, Marankan F, Mulhearn DC, Wanna L et al (2003) Regioselective covalent modification of hemoglobin in search of antisickling agents. J Med Chem 46:936-953

Pauline N, Cabral BNP, Anatole PC, Jocelyne AMV, Bruno M, Jeanne NY (2013) The in vitro antisickling and antioxidant effects of aqueous extracts Zanthoxyllum heitzii on sickle cell disorder. BMC Compl Altern Med 13(1):162

Piccin A, Murphy C, Eakins E, Rondinelli MB, Daves M, Vecchiato C (2019) Insights into the complex pathophysiology of sickle cell anaemia and possible treatment. Eur J Haematol 2019:1-12

Pinto MEA, Araújo SG, Morais MI, Sá NP, Lima CM (2017) Antifungal and antioxidant activity of fatty acid methyl esters from vegetable oils. Ann Braz Acad Sci 89(3):1671-1181

Rašković A, Pavlović N, Kvrgić M, Sudji J, Mitić G, Čapo I (2015) Effects of pharmaceutical formulations containing thyme on carbon tetrachlorideinduced liver injury in rats. BMC Compl Altern Med 15:442

Rotter MA, Kwong S, Briehl RW, Ferrone FA (2005) Heterogeneous nucleation in sickle hemoglobin: Experimental validation of a structural mechanism. Biophys J 89:2677-2684

Safo MK, Kato GJ (2014) Therapeutic strategies to alter the oxygen affinity of sickle haemoglobin. Haematol Oncol Clin N Am 28:17

Sampaio KL, Garruti DS, Franco MRB, Janzantti NS, Da Silva MAP (2011) Aroma volatiles recovered in the water phase of cashew apple (Anacardium occidentale L.) juice during concentration. J Sci Food Agric 91:1801-1809

Sarkar S, Khan MF, Kaphalia BS, Ansari GA (2006) Methyl palmitate inhibits lipopolysaccharide-stimulated phagocytic activity of rat peritoneal macrophages. J Biochem Mol Toxicol 20:302-308

Sasidharan S, Chen Y, Saravanan D, Sundram KM, Yoga LL (2011) Extraction, isolation and characterization of bioactive compounds from plants' extracts. Afr J Tradit Compl Altern Med 8:1-10

Saxena M, Saxena J, Nema R, Singh D, Gupta A (2013) Phytochemistry of medicinal plants. J Pharmacogn Phytochem 1(6):168-170

Semwa P, Painuli S (2019) Antioxidant, antimicrobial, and GC-MS profiling of Saussurea obvallata (Brahma Kamal) from Uttarakhand Himalaya. Clin Phytosci 5:12, 11 pages

Setty BNY, Kulkarni S, Rao AK, Stuart MJ (2000) Fetal hemoglobin in sickle cell disease: relationship to erythrocyte phosphatidylserine exposure and coagulation activation. Blood 96(3):1119-1124

Stallworth JR, Jerrell JM, Tripathi A (2010) Cost-effectiveness of hydroxyurea in reducing the frequency of pain episodes and hospitalization in pediatric sickle cell disease. Am J Haematol 85(10):795-797

Syed MM, Doshi PJ, Dhavale DD, Doshi JB, Kate SL et al (2019) Potential of isoquercitrin as antisickling agent: a multi-spectroscopic, thermophoresis and molecular modeling approach. J Biomole Strut Dyn 2019:20 pages. https:// doi.org/10.1080/07391102.2019.1645735

Tsakiris S, Giannoulia-Karantana A, Simintzi I, Schulpis KH (2005) The effect of aspartame metabolites on human erythrocyte membrane acetylcholinesterase activity. Pharmacol Res 53:1-5

Uwakwe AA, Nwaoguikpe RN (2008) In vitro antisickling effects of Xylopia aéthiopica and Monodora myristica. J Med Plant Res 2:119-124

Uzunova W, Pan W, Galkin O, Vekilov PG (2010) Free heme and the polymerization of sickle cell hemoglobin. Biophys J 99:1976-1985

Vekilov PG (2007) Sickle-cell haemoglobin polymerization: is it the primary pathogenic event of sickle cell anaemia? Br J Haematol 139(2):173-184

Vijisaral ED, Arumugam S (2014) GC-MS analysis of bioactive constituents of Indigofera suffruticosa leaves. J Chem Pharmaceut Res 6(8):294-300 
Weatherall DJ, Akinyanju O, Fucharoen S, Olivieri NF, Musgrove P (2006) Inherited disorders of hemoglobin. In: Disease Control Priorities in Developing Countries. D. Editor. Oxford University Press. New York. USA, Jamison, pp 663-680

World Health Organization Regional Office for Africa. Sickle-cell disease: a strategy for the WHO African Region. Report of the Regional Director. Geneva, Switzerland: WHO, 22 June 2010. AFR/RC60/8.

Xu ASL, Labotka RJ, London RE (1999) Acetylation of human hemoglobin by methyl acetylphosphate: Evidence of broad regio-selectivity revealed by NMR studies. J Biol Chem 274:26629-26632

Yamamoto A, Saito N, Yamauchi Y, Takeda M, Ueki S, Itoga M et al (2014) Flow cytometric analysis of red blood cell osmotic fragility. J Lab Auto 19(5):483-487

\section{Publisher's Note}

Springer Nature remains neutral with regard to jurisdictional claims in published maps and institutional affiliations.

\section{Submit your manuscript to a SpringerOpen ${ }^{\circ}$ journal and benefit from:}

- Convenient online submission

- Rigorous peer review

- Open access: articles freely available online

High visibility within the field

- Retaining the copyright to your article

Submit your next manuscript at $\boldsymbol{\nabla}$ springeropen.com 